Supplement of Earth Syst. Sci. Data, 12, 1897-1912, 2020

https://doi.org/10.5194/essd-12-1897-2020-supplement

(C) Author(s) 2020. This work is distributed under

the Creative Commons Attribution 4.0 License.

(c) (1)

Supplement of

\title{
The fate of land evaporation - a global dataset
}

Andreas Link et al.

Correspondence to: Andreas Link (andreas.link@tu-berlin.de)

The copyright of individual parts of the supplement might differ from the CC BY 4.0 License. 


\section{General information on the content of the supporting information (SI)}

The first part of the SI provides the following supplementary figures in order to display the sample evaporationsheds of the

Based on sample scripts provided within the dataset, average monthly or yearly evaporationsheds can be plotted for any land grid cell, country or basin of interest. An additional online viewer can be used to directly look up plots for any land grid cell.

The dataset and the online viewer are accessable under the following URLs:

○ Dataset: https://doi.org/10.1594/PANGAEA.908705 (Link et al., 2019a)

○ Online viewer: http://wf-tools.see.tu-berlin.de/wf-tools/evaporationshed/\#/ (Link et al., 2019b)
55

Afterwards, the supplementary materials regarding chapter 4.2 of the main article are provided, which refer to the critical reflections on the used input data. They include:

- Plots regarding the average daily evaporation and precipitation based on the ERA-Interim (ERA-I) reanalysis (Berrisford et al., 2011; Dee et al., 2011) (Figure S37)

$60 \quad 0$ Plotted differences between the ERA-I (Berrisford et al., 2011; Dee et al., 2011) and ERA5 reanalysis (Hersbach et al., 2020) regarding the average daily evaporation and precipitation (Figure S38)

- Methodological details regarding the continental comparison of the average evaporation and precipitation between ERA-I (Berrisford et al., 2011; Dee et al., 2011), ERA5 (Hersbach et al., 2020) and the study by Rodell et al. (2015)

○ Grouping procedure for the aggregation of the ERA-I (Berrisford et al., 2011; Dee et al., 2011) and ERA5 data 65 (Hersbach et al., 2020) on evaporation and precipitation to continental scales (Table S1) 
The last part of the SI is given in table format and is related to chapter 4.3 of the main article ("Comparison to other datasets"). It provides the following materials:

- Overall comparison between the country results of the 3D quasi-isentropic back-trajectory (3D QIBT) method by Dirmeyer et al. (2009) and the WAM-2layers model (Van der Ent, 2014) (Table S2)

- In this context, all comparable values for the terrestrial evaporative source (TES - unit: \%) as well as the country internal evaporative source (CIES - unit: \%) of precipitation are listed

- Top 10 sources of precipitation for the sample countries Brazil, Egypt and Laos - Comparison between results of the 3D QIBT (Dirmeyer et al., 2009) and the WAM-2layers model (Van der Ent, 2014) (Table S3 to Table S5) 


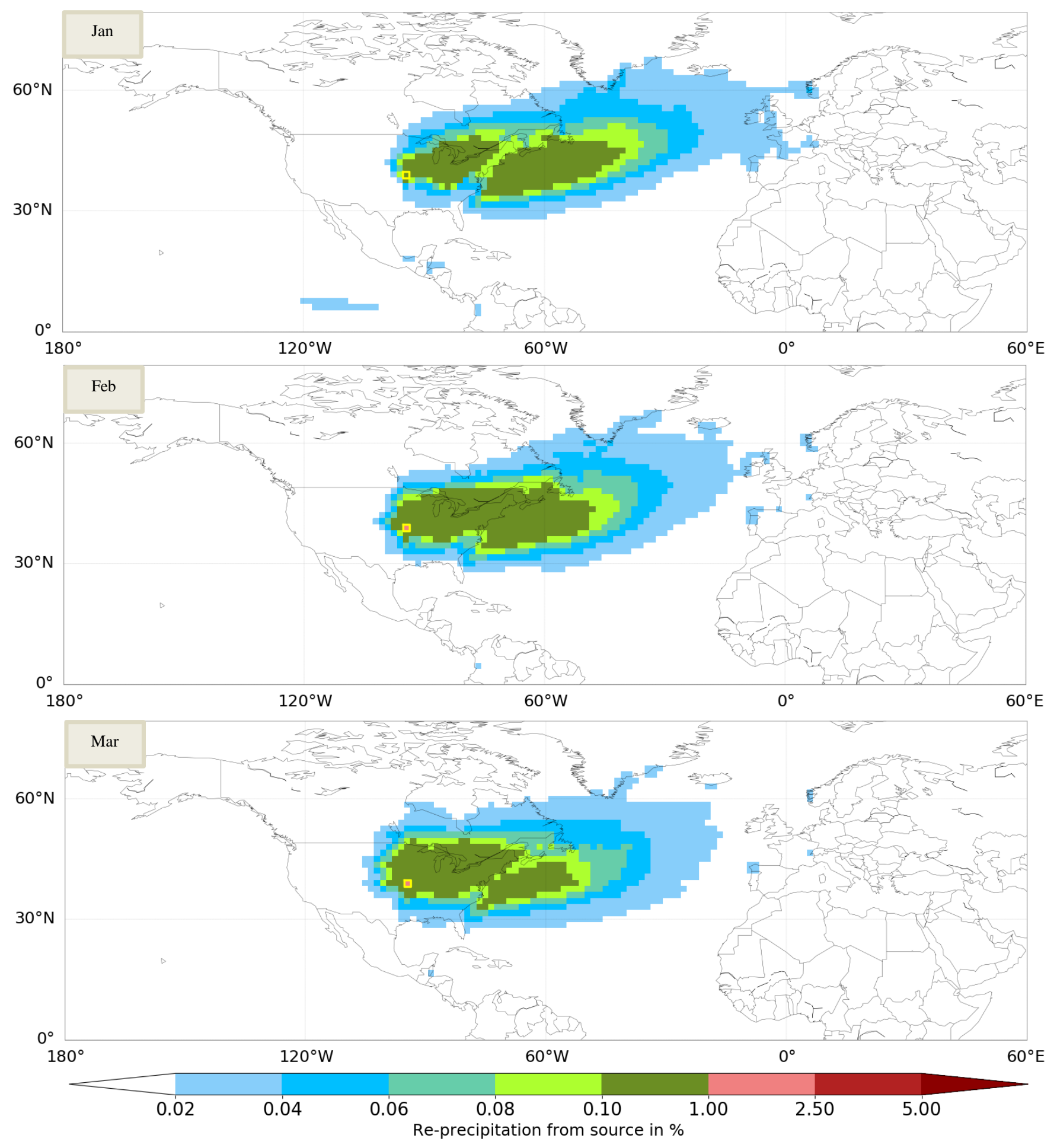

Figure S1 Monthly evaporationsheds (Jan = January, Feb $=$ February, Mar $=$ March) for the grid cell at 39.0 ${ }^{\circ} \mathrm{N}$ latitude $\& 94.5^{\circ} \mathrm{W}$ longitude (Kansas City, US), $E_{\text {input }}: 16.2$ mm/month (Jan) / 23.1 mm/month (Feb) / 50.8 mm/month (Mar), Unassigned : 1.2 \% (Jan) / $1.1 \%$ (Feb) / $0.9 \%$ (Mar), Colored area covers $73.8 \%$ (Jan) / $75.5 \%$ (Feb) / $75.4 \%$ (Mar) of the assigned water 

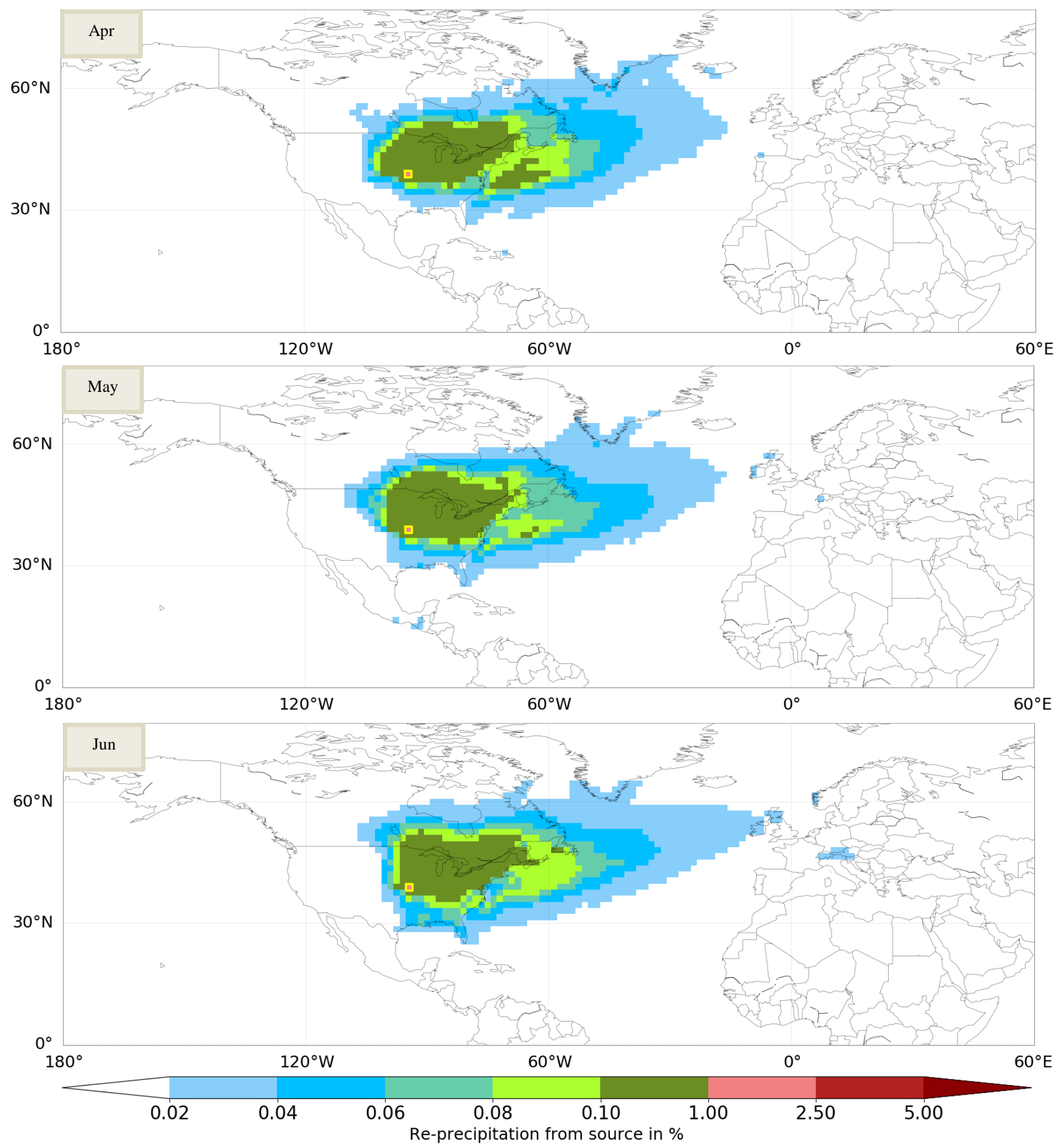

Figure S2 Monthly evaporationsheds $($ Apr $=$ April, May, Jun = June $)$ for the grid cell at 39.0 ${ }^{\circ} \mathrm{N}$ latitude $\& 94.5^{\circ} \mathrm{W}$ longitude $($ Kansas City, US), $E_{\text {input }}: 76.7$ mm/month (Apr) / 113.0 mm/month (May) / 137.9 mm/month (Jun), Unassigned : $1.3 \%$ (Apr) / $1.6 \%$ (May) / $2.5 \%$ (Jun), Colored area covers $73.9 \%$ (Apr) / $73.9 \%$ (May) / $74.4 \%$ (Jun) of the assigned water 


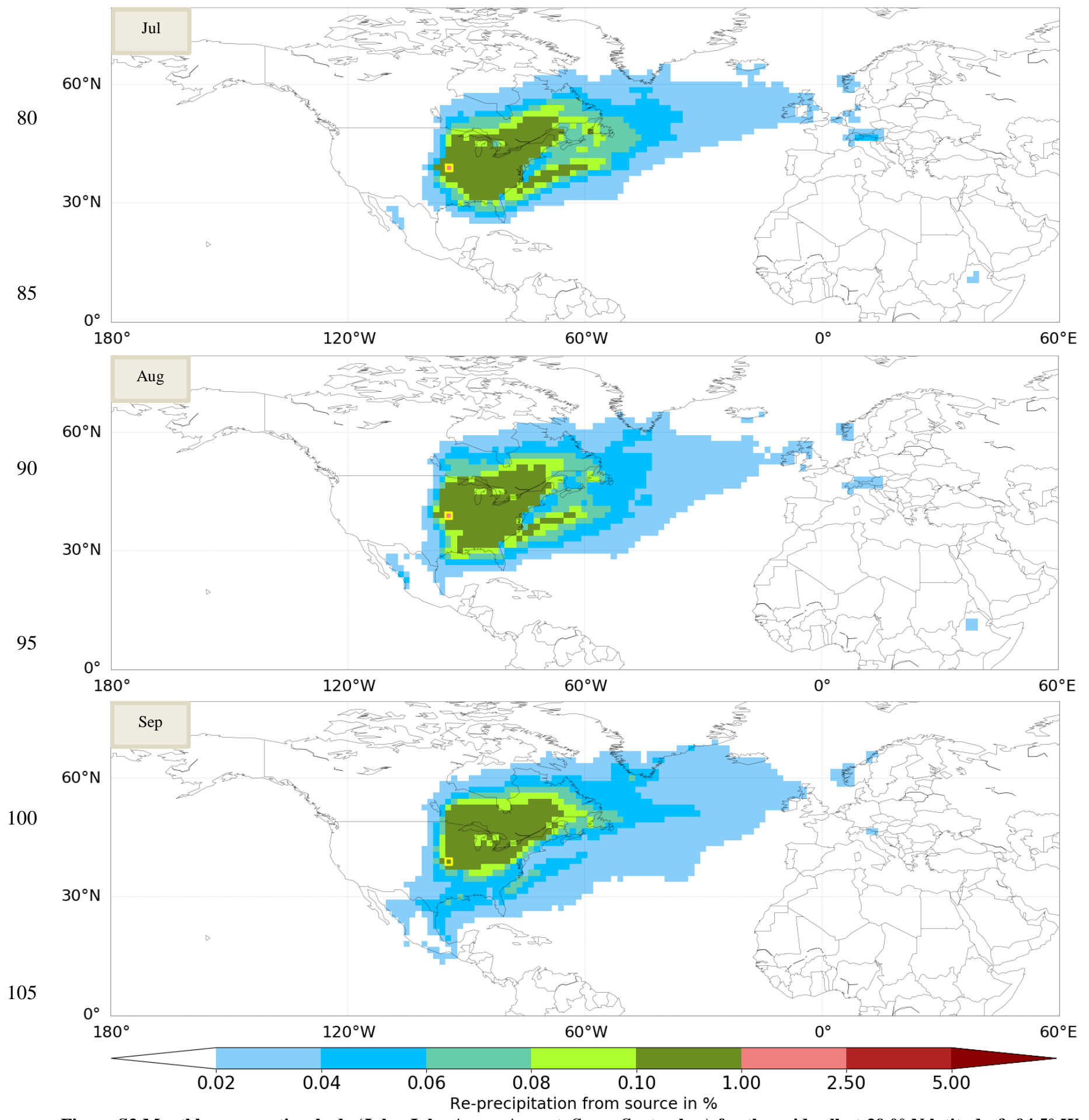

Figure S3 Monthly evaporationsheds $(\mathrm{Jul}=\mathrm{July}$, Aug = August, Sep = September $)$ for the grid cell at $39.0^{\circ} \mathrm{N}$ latitude $\& 94.5^{\circ} \mathrm{W}$ longitude (Kansas City, US), $E_{\text {input }}: 144.0$ mm/month (Jul) / 121.6 mm/month (Aug) / 87.1 mm/month (Sep), Unassigned : $3.4 \%$ (Jul) / $2.6 \%$ (Aug) / $3.0 \%$ (Sep), Colored area covers 71.0 \% (Jul) / $68.9 \%$ (Aug) / $68.9 \%$ (Sep) of the assigned water 


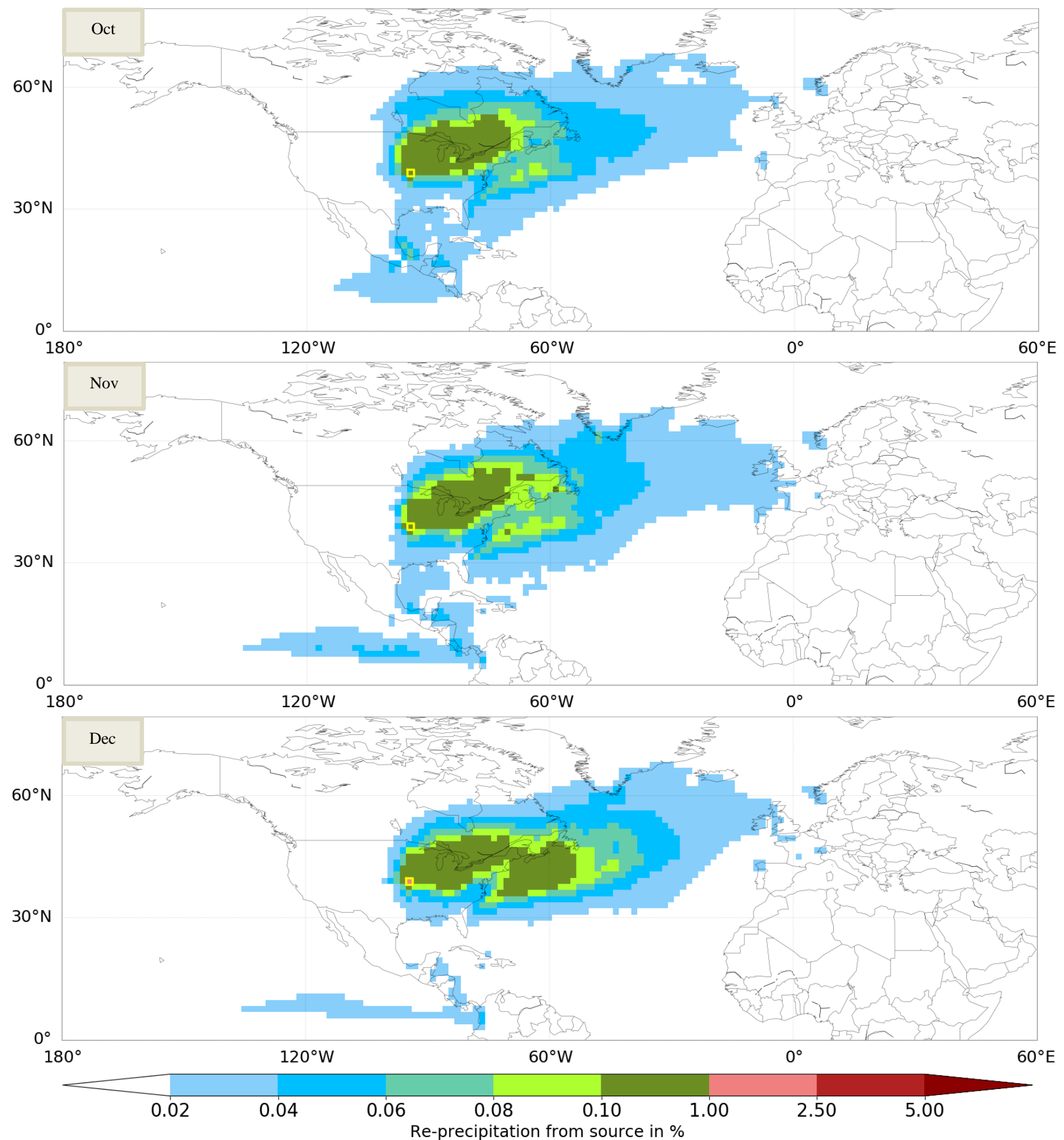

Figure S4 Monthly evaporationsheds $($ Oct $=$ October, Nov $=$ November, Dec $=$ December $)$ for the grid cell at $39.0^{\circ} \mathrm{N}$ latitude $\& 94.5^{\circ}$ W longitude (Kansas City, US), $E_{\text {input }}: 54.3 \mathrm{~mm} / \mathrm{month}$ (Oct) / $30.1 \mathrm{~mm} / \mathrm{month}$ (Nov) / $16.8 \mathrm{~mm} / \mathrm{month}$ (Dec), Unassigned : $2.6 \%$ (Oct) / $1.5 \%$ (Nov) / $1.2 \%$ (Dec), Colored area covers $68.3 \%$ (Oct) / $71.1 \%$ (Nov) / $71.1 \%$ (Dec) of the assigned water 

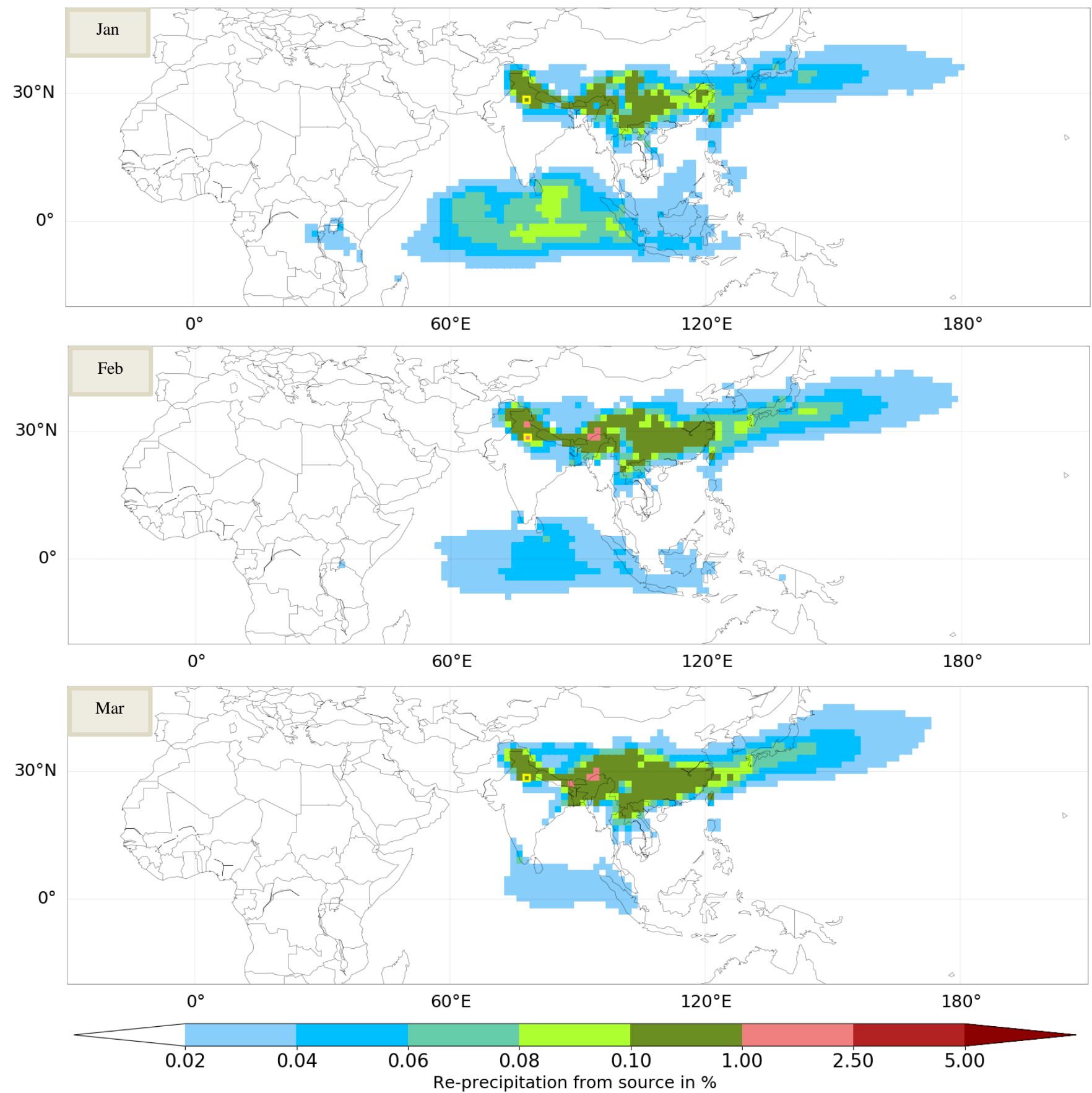

Figure S5 Monthly evaporationsheds (Jan = January, Feb = February, Mar $=$ March) for the grid cell at $28.5^{\circ} \mathrm{N}$ latitude $\& 78.0^{\circ} \mathrm{E}$ longitude (Delhi, India), $E_{\text {input }}: 52.3 \mathrm{~mm} / \mathrm{month}$ (Jan) / $67.7 \mathrm{~mm} / \mathrm{month}($ Feb) / $98.1 \mathrm{~mm} / \mathrm{month}$ (Mar), Unassigned : 0.1 \% (Jan) / $0.1 \%$ (Feb) / $0.2 \%$ (Mar), Colored area covers $72.2 \%$ (Jan) / $72.9 \%$ (Feb) / 75.0 \% (Mar) of the assigned water 


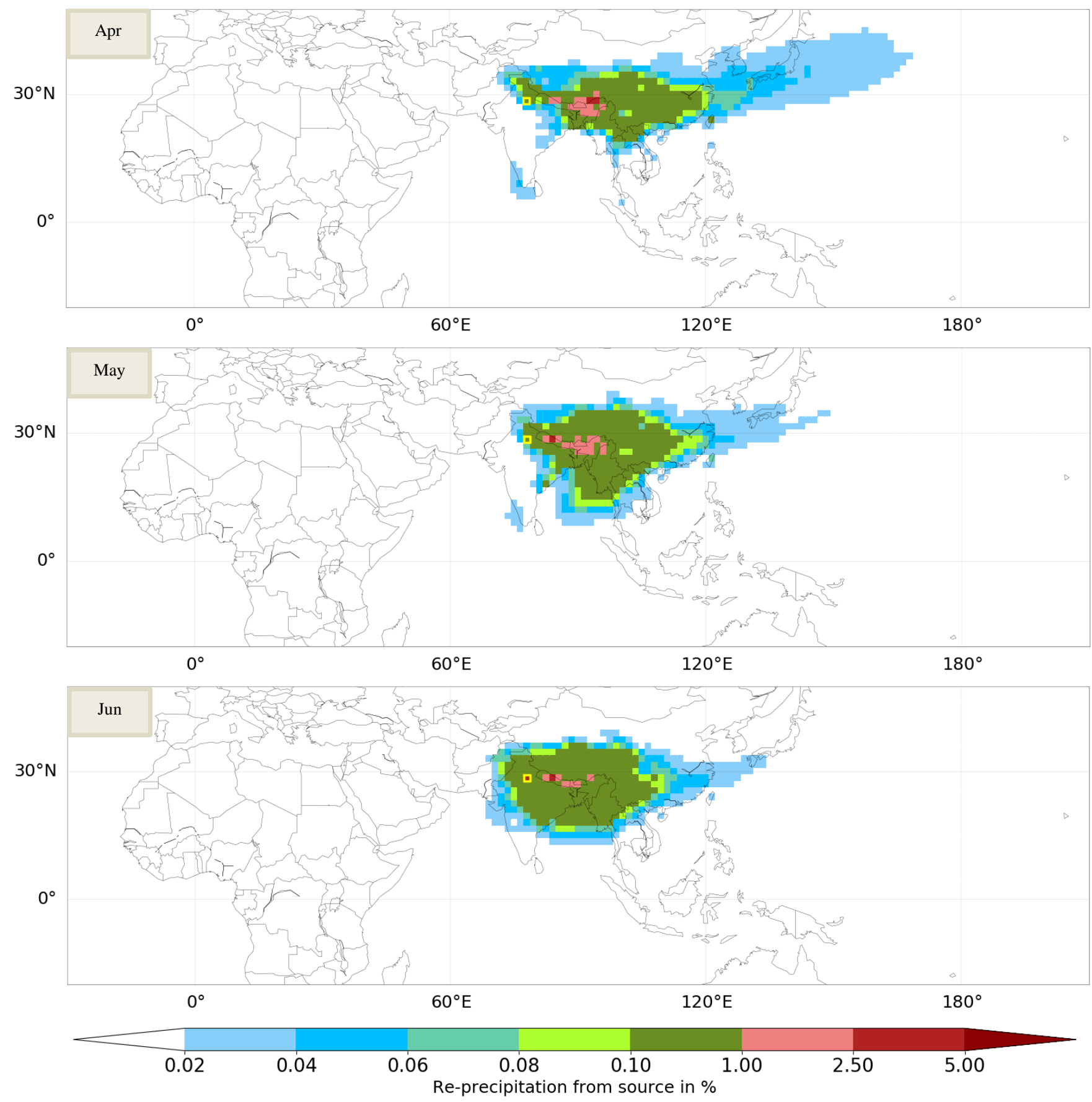

Figure S6 Monthly evaporationsheds $\left(\mathrm{Apr}=\right.$ April, May, Jun $=$ June) for the grid cell at $28.5^{\circ} \mathrm{N}$ latitude \& $78.0^{\circ} \mathrm{E}$ longitude $(\mathrm{Delhi}$, India), $E_{\text {input }}: 96.4$ mm/month (Apr) / 110.5 mm/month (May) / 113.8 mm/month (Jun), Unassigned : $0.2 \%$ (Apr) / $0.3 \%$ (May) / $0.2 \%$ (Jun), Colored area covers $79.4 \%$ (Apr) / $84.4 \%$ (May) / 89.0 \% (Jun) of the assigned water 

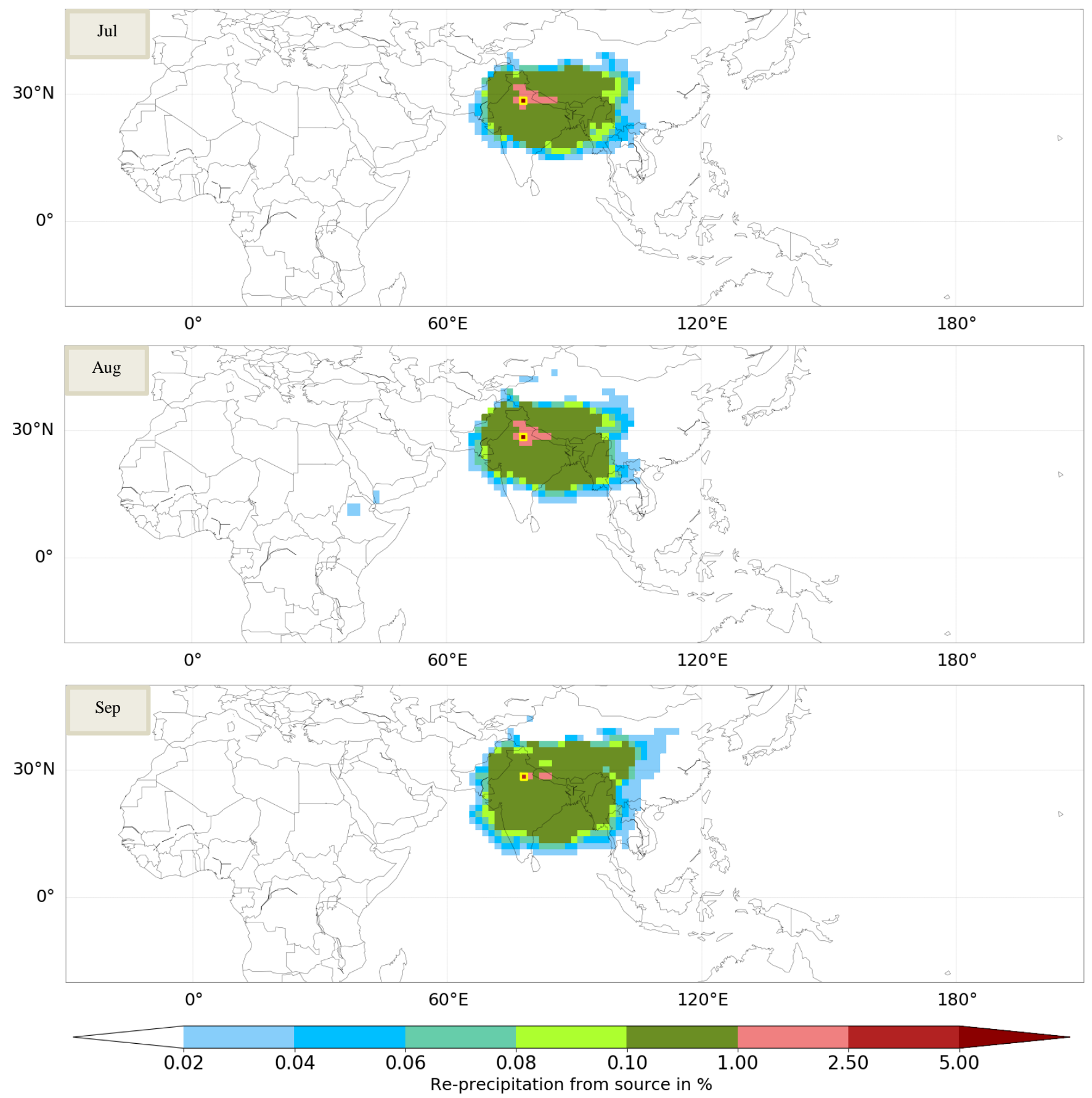

Figure S7 Monthly evaporationsheds (Jul = July, Aug = August, Sep = September) for the grid cell at $28.5^{\circ} \mathrm{N}$ latitude \& $78.0^{\circ} \mathbf{E}$ longitude (Delhi, India), $E_{\text {input }}: 130.4$ mm/month (Jul) / 130.6 mm/month (Aug) / 123.4 mm/month (Sep), Unassigned : $0.2 \%$ (Jul) / $0.1 \%$ (Aug) / $0.1 \%$ (Sep), Colored area covers $93.4 \%$ (Jul) / $93.8 \%$ (Aug) / $91.9 \%$ (Sep) of the assigned water 

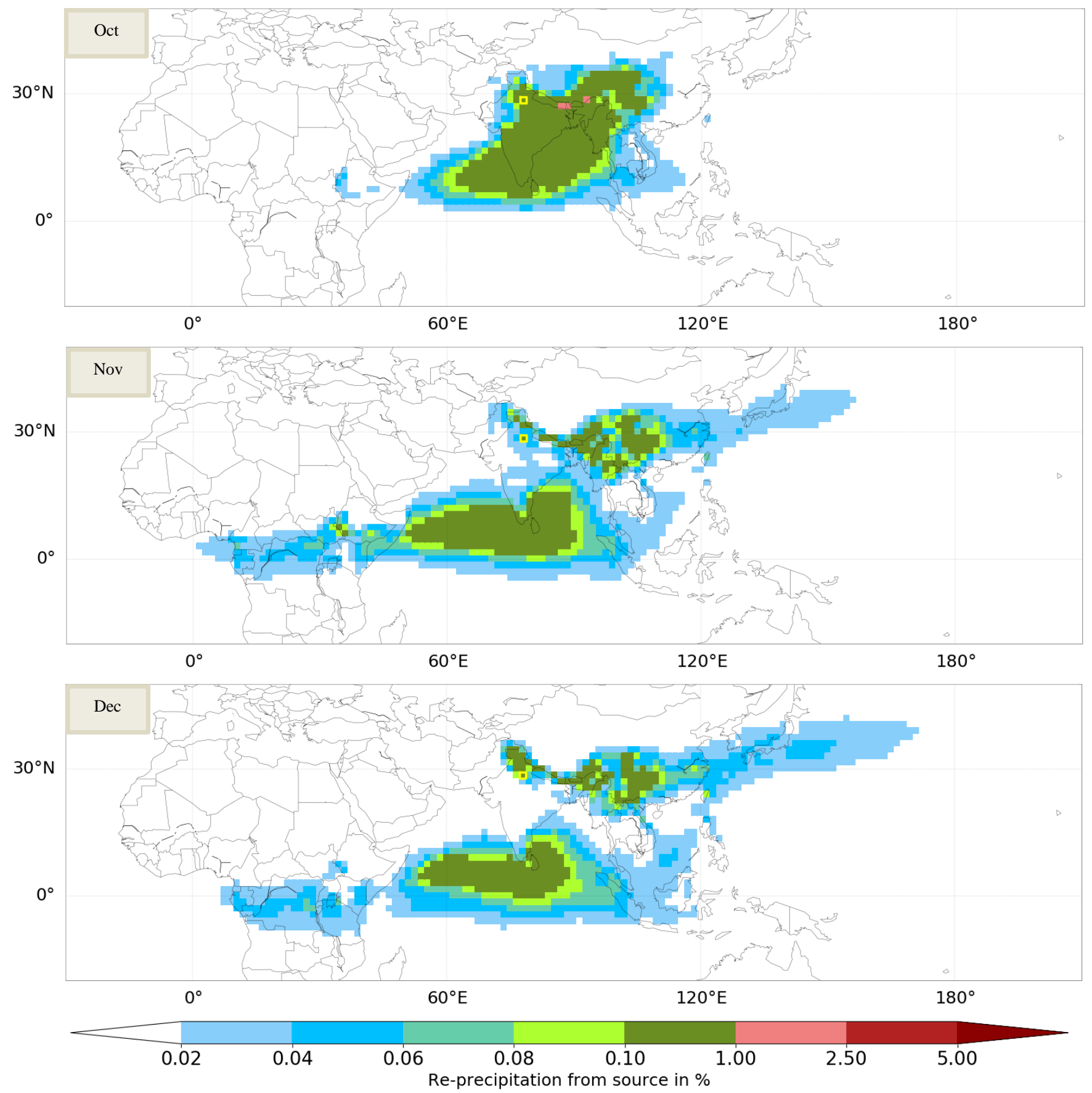

Figure S8 Monthly evaporationsheds $($ Oct $=$ October, Nov $=$ November, Dec $=$ December $)$ for the grid cell at $28.5^{\circ} \mathrm{N}$ latitude \& 78.0 E longitude (Delhi, India), $E_{\text {input }}: 101.2 \mathrm{~mm} / \mathrm{month}($ Oct) / $62.1 \mathrm{~mm} / \mathrm{month}$ (Nov) / $46.2 \mathrm{~mm} / \mathrm{month}$ (Dec), Unassigned : $0.1 \%$ (Oct) / $0.1 \%$ (Nov) / $0.1 \%$ (Dec), Colored area covers $85.3 \%$ (Oct) / $78.5 \%$ (Nov) / $74.1 \%$ (Dec) of the assigned water 
115
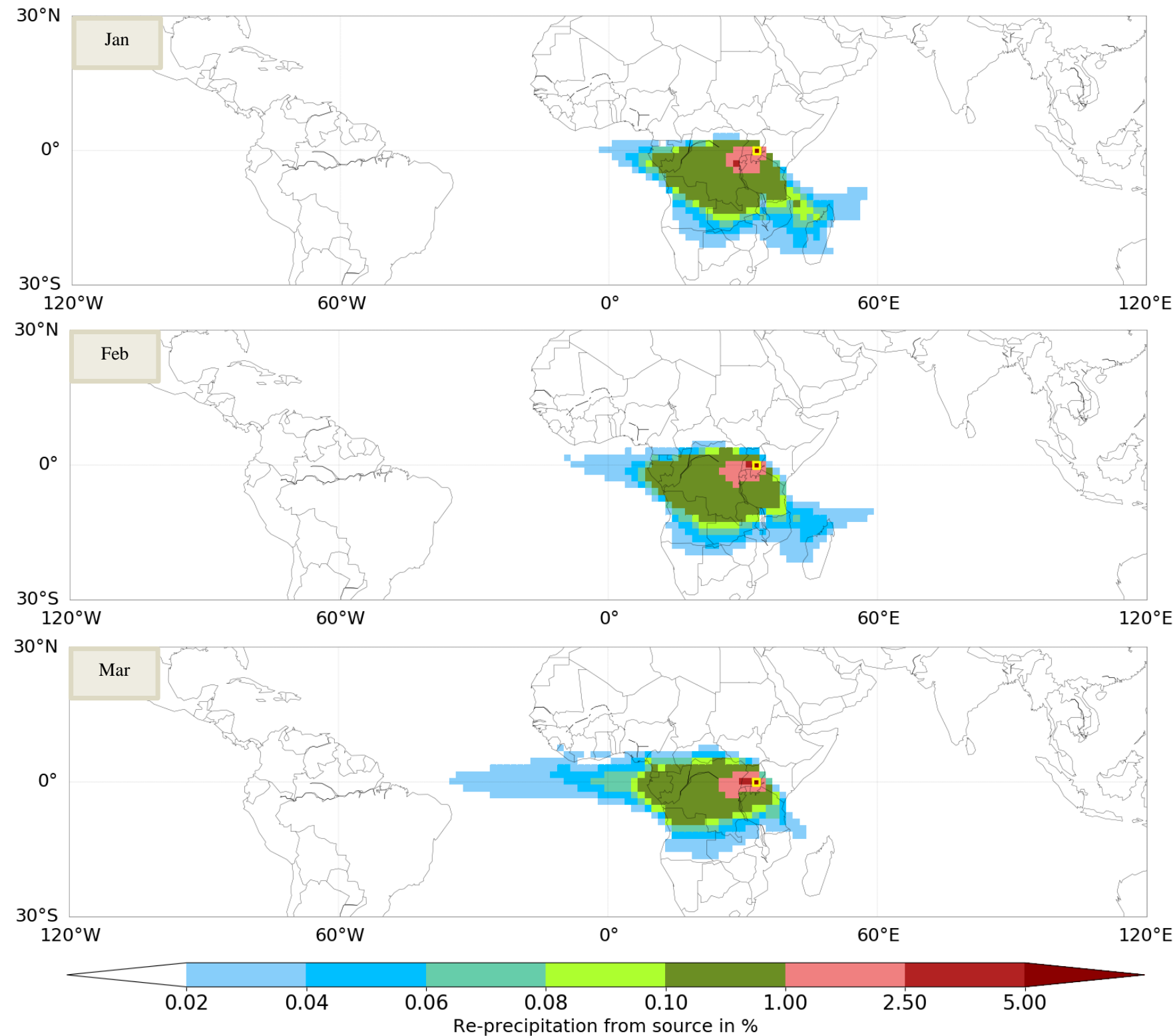

Figure S9 Monthly evaporationsheds $\left(\mathrm{Jan}=\right.$ January, Feb $=$ February, Mar $=$ March) for the grid cell at $0.0^{\circ}$ latitude $\& 33.0^{\circ} \mathbf{E}$ longitude (Kampala, Uganda), $E_{\text {input }}: 104.5 \mathrm{~mm} / \mathrm{month}(\mathrm{Jan}) / 103.5 \mathrm{~mm} / \mathrm{month}(\mathrm{Feb}) / 108.9 \mathrm{~mm} / \mathrm{month}$ (Mar), Unassigned : $0.0 \%$ (Jan) / $0.0 \%$ (Feb) / $0.0 \%$ (Mar), Colored area covers $92.1 \%$ (Jan) / $92.0 \%$ (Feb) / $92.6 \%$ (Mar) of the assigned water 

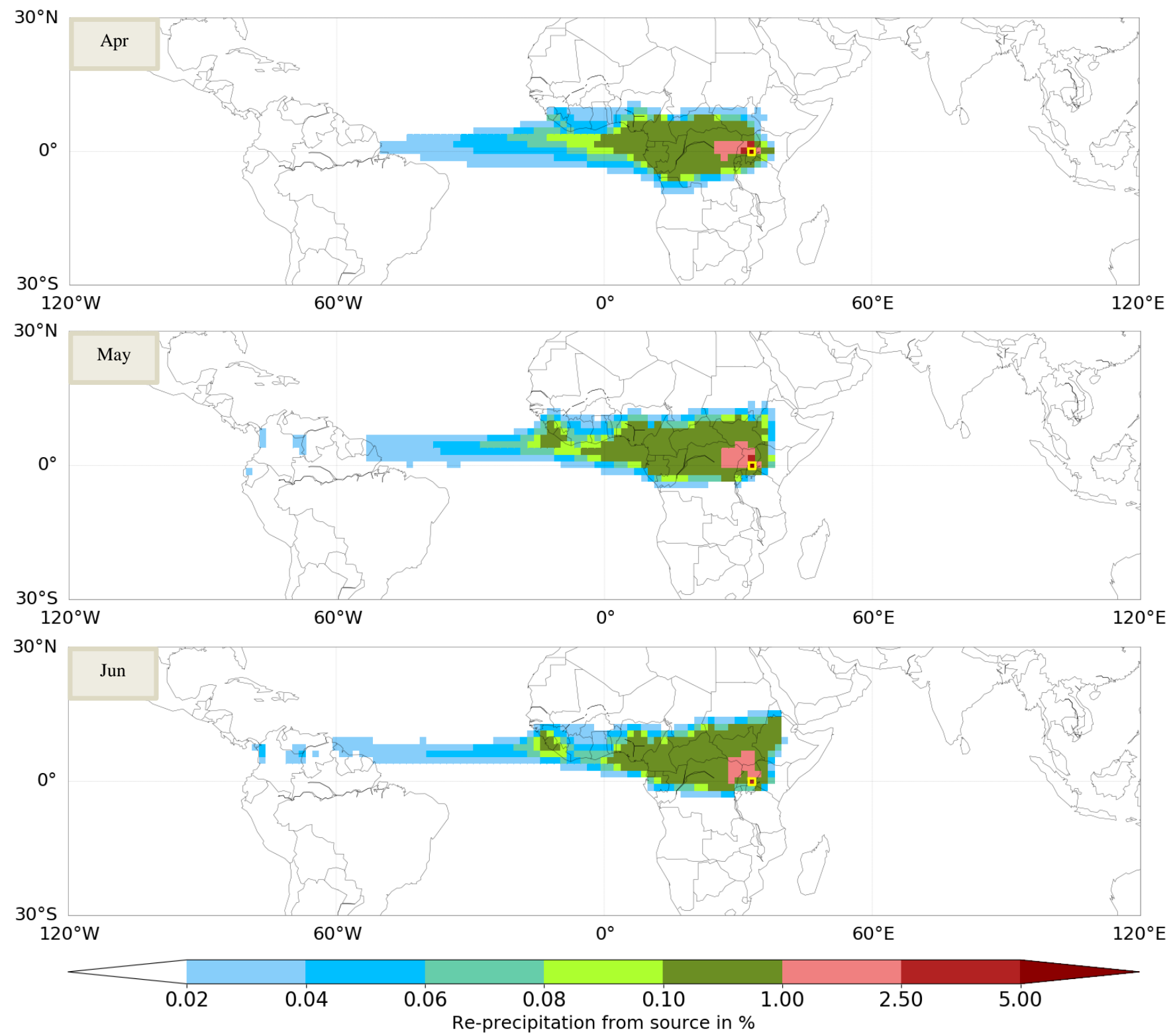

Figure S10 Monthly evaporationsheds (Apr = April, May, Jun = June) for the grid cell at $0.0^{\circ}$ latitude \& 33.0 ${ }^{\circ}$ E longitude $($ Kampala, Uganda), $E_{\text {input }}: 93.3 \mathrm{~mm} / \mathrm{month}$ (Apr) / $92.8 \mathrm{~mm} / \mathrm{month}$ (May) / $86.8 \mathrm{~mm} / \mathrm{month}$ (Jun), Unassigned : $0.0 \%$ (Apr) / $0.0 \%$ (May) / $0.0 \%$ (Jun), Colored area covers $93.8 \%$ (Apr) / $92.1 \%$ (May) / $89.4 \%$ (Jun) of the assigned water 

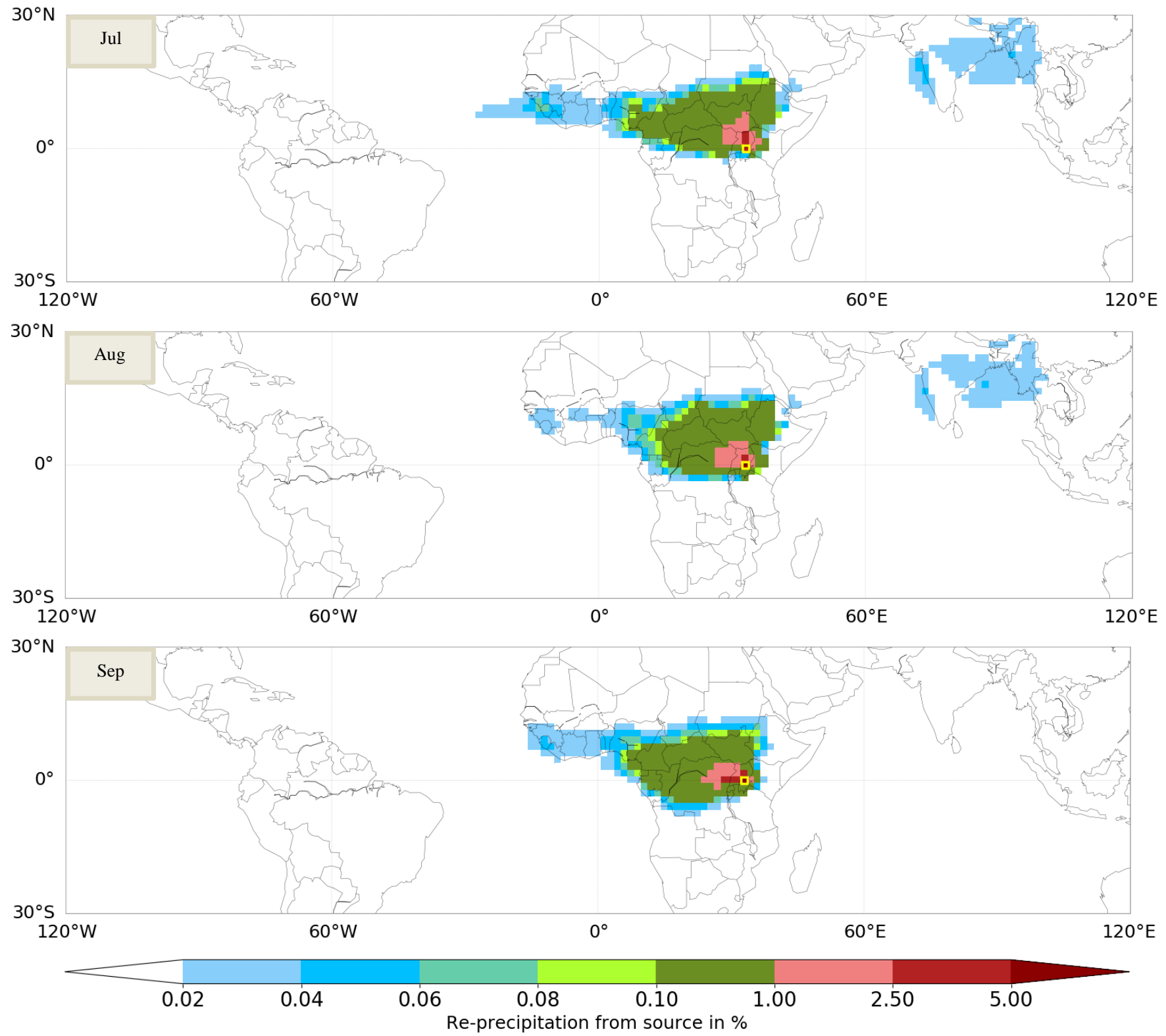

Figure S11 Monthly evaporationsheds $(\mathrm{Jul}=\mathrm{July}$, Aug $=$ August, Sep $=$ September $)$ for the grid cell at $0.0^{\circ}$ latitude $\& 33.0^{\circ} \mathrm{E}$ longitude (Kampala, Uganda), $E_{\text {input }}: 87.7$ mm/month (Jul) / 88.0 mm/month (Aug) / 93.9 mm/month (Sep), Unassigned : $0.0 \%$ (Jul) / $0.0 \%$ (Aug) / $0.0 \%$ (Sep), Colored area covers $88.6 \%$ (Jul) / 89.3\% (Aug) / 92.6 \% (Sep) of the assigned water 

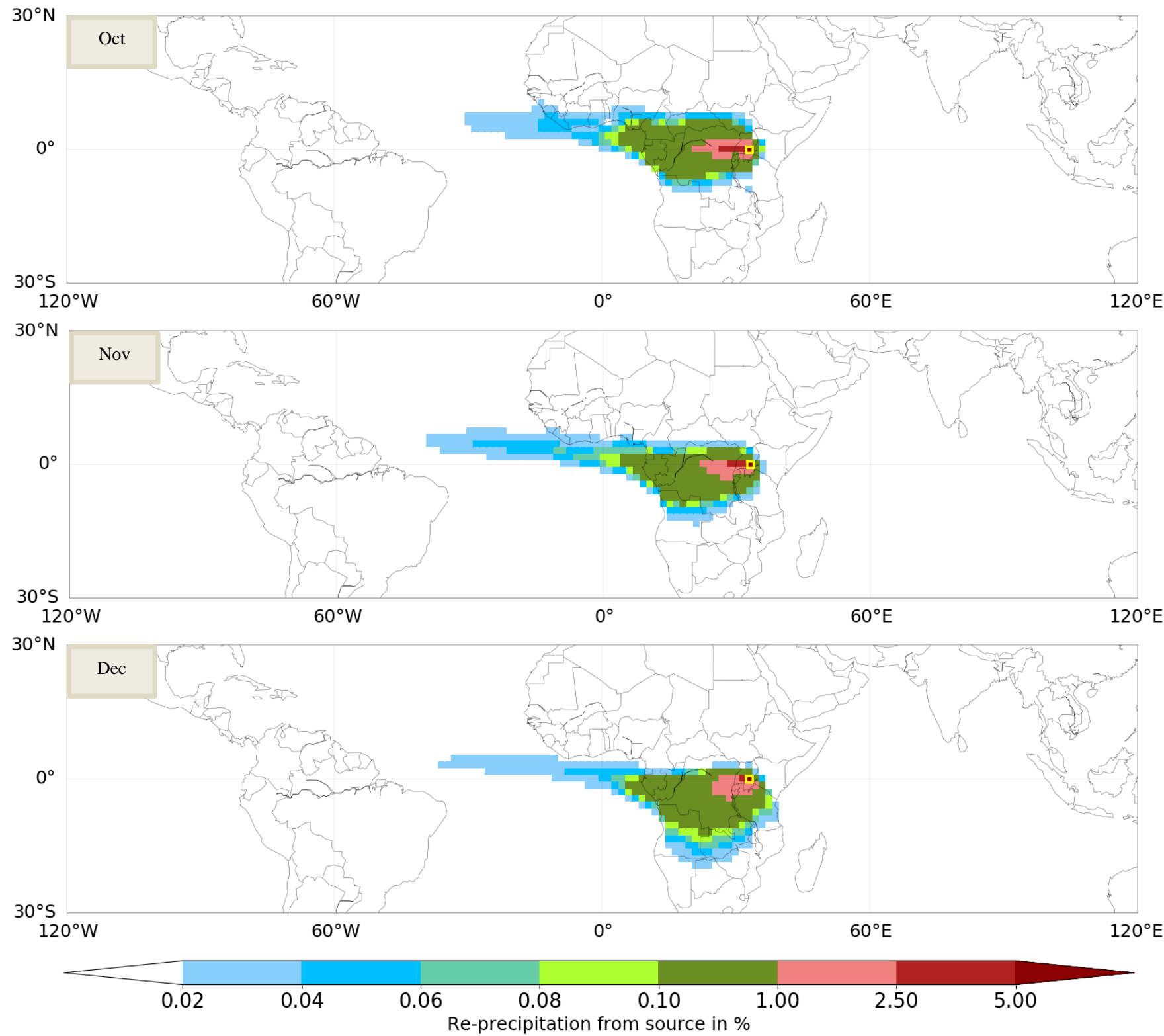

Figure S12 Monthly evaporationsheds $($ Oct $=$ October, Nov $=$ November, Dec $=$ December $)$ for the grid cell at $0.0^{\circ}$ latitude $\& 33.0^{\circ}$ E longitude (Kampala, Uganda), $E_{\text {input }}: 97.4 \mathrm{~mm} / \mathrm{month}($ Oct) $/ 92.8 \mathrm{~mm} / \mathrm{month}$ (Nov) $/ 95.5 \mathrm{~mm} / \mathrm{month}$ (Dec), Unassigned : $0.0 \%$ (Oct) / $0.0 \%$ (Nov) / $0.0 \%$ (Dec), Colored area covers $94.2 \%$ (Oct) / $94.2 \%$ (Nov) / 93.1 \% (Dec) of the assigned water 


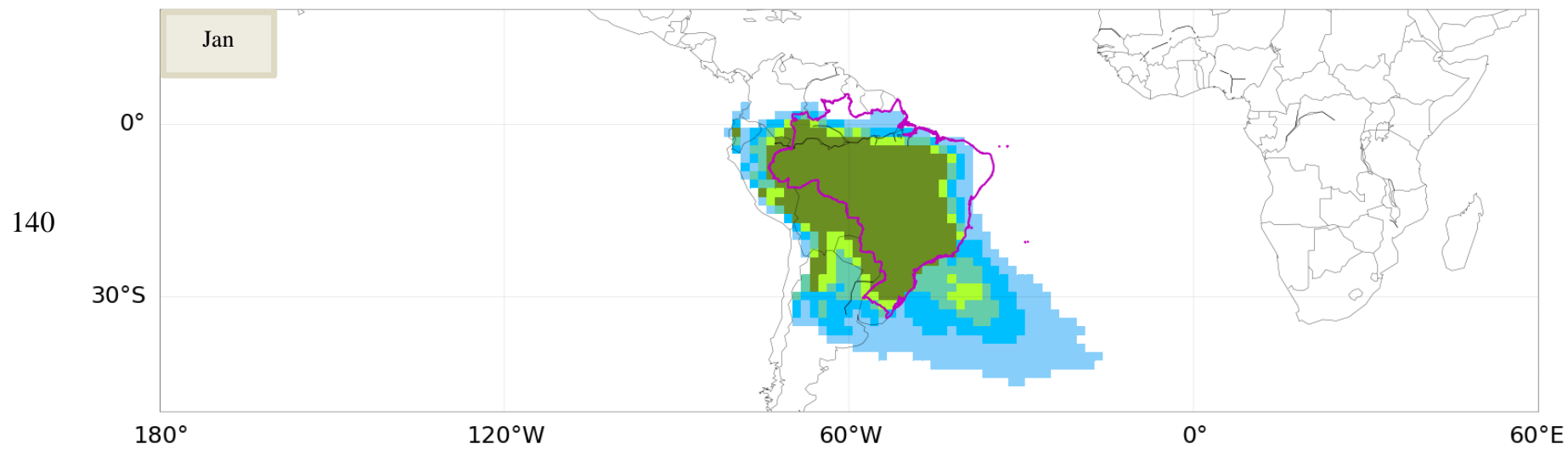

145

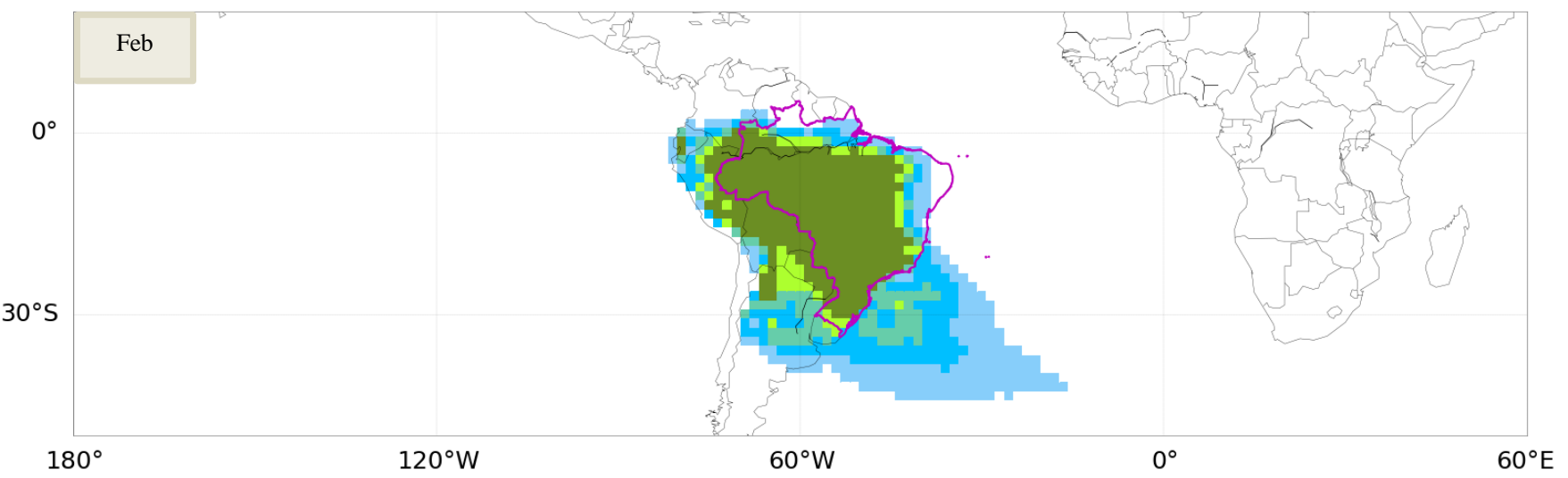

155

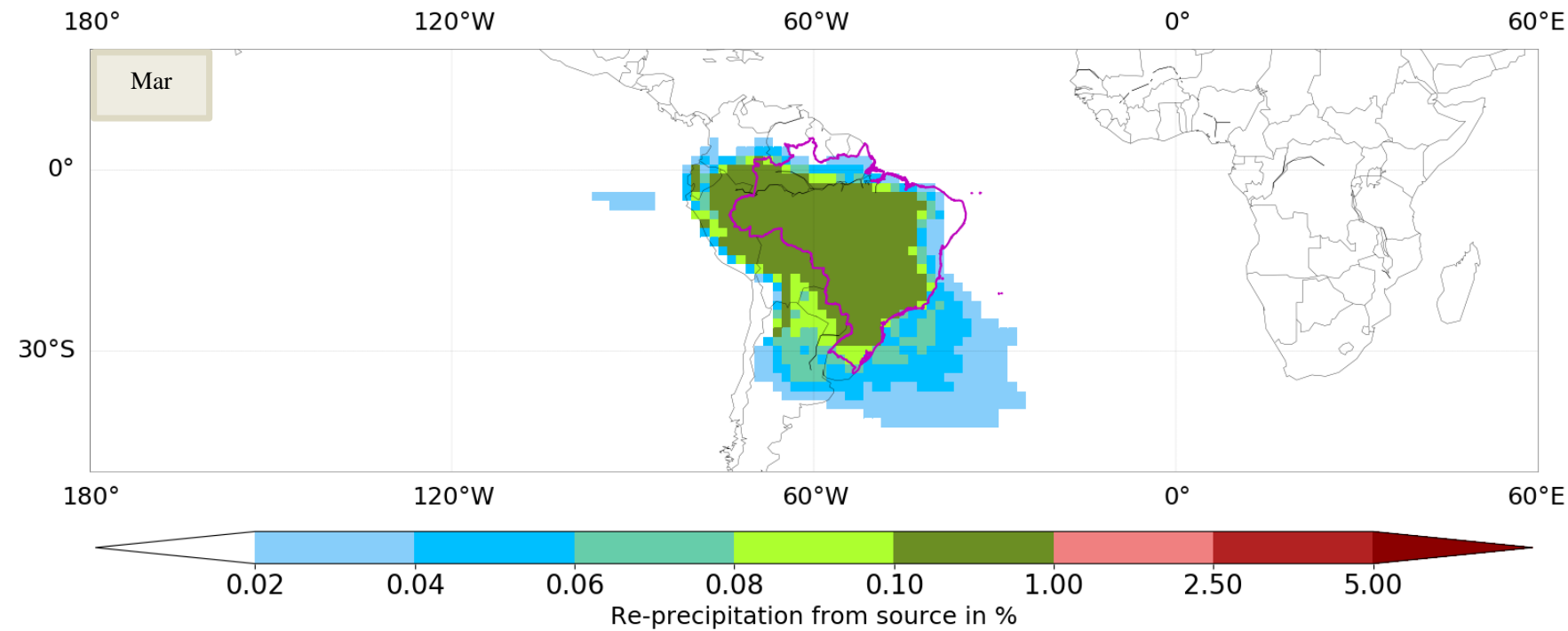

165 Figure S13 Monthly evaporationsheds (Jan = January, Feb = February, Mar = March) for Brazil , $E_{\text {input }}: 118.3 \mathrm{~mm} / \mathrm{month}(\mathrm{Jan}) /$ $107.7 \mathrm{~mm} /$ month (Feb) / $115.1 \mathrm{~mm} /$ month (Mar), Unassigned : $0.1 \%$ (Jan) / $0.1 \%$ (Feb) / $0.1 \%$ (Mar), Colored area covers 82.9 $\%(\mathrm{Jan}) / 83.4 \%(\mathrm{Feb}) / 83.9 \%$ (Mar) of the assigned water 
170

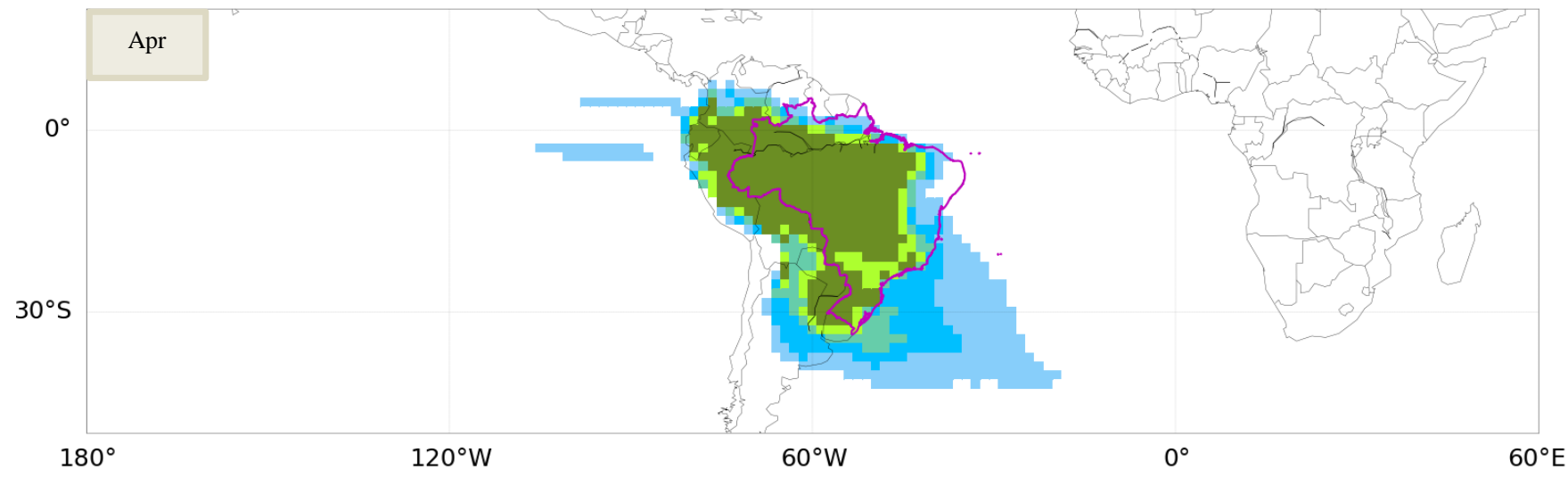

180

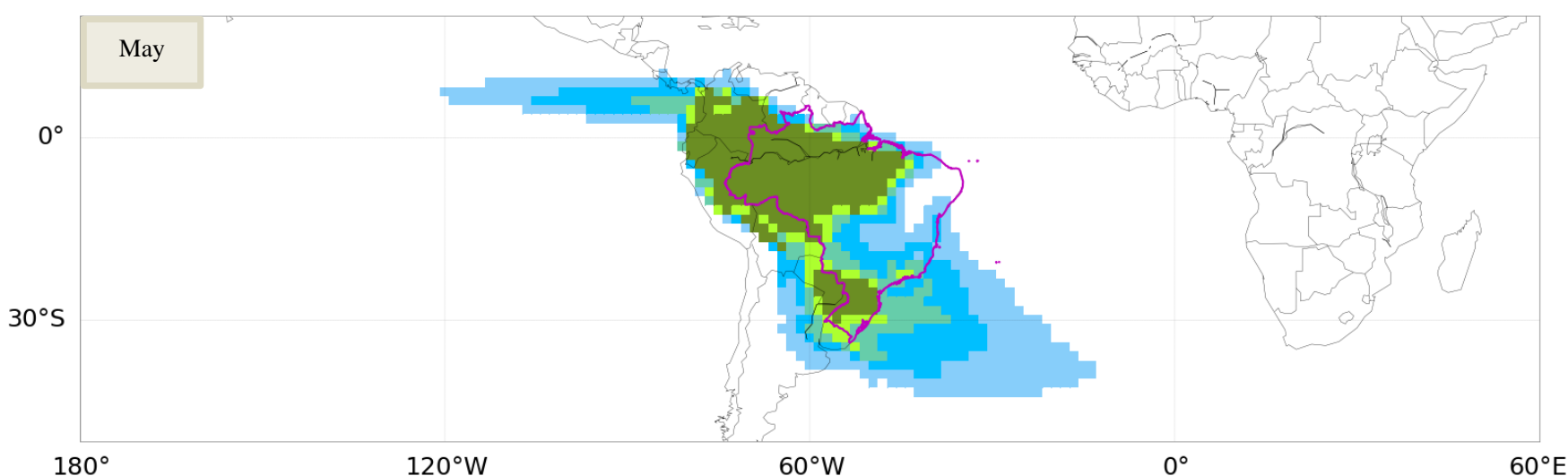

190

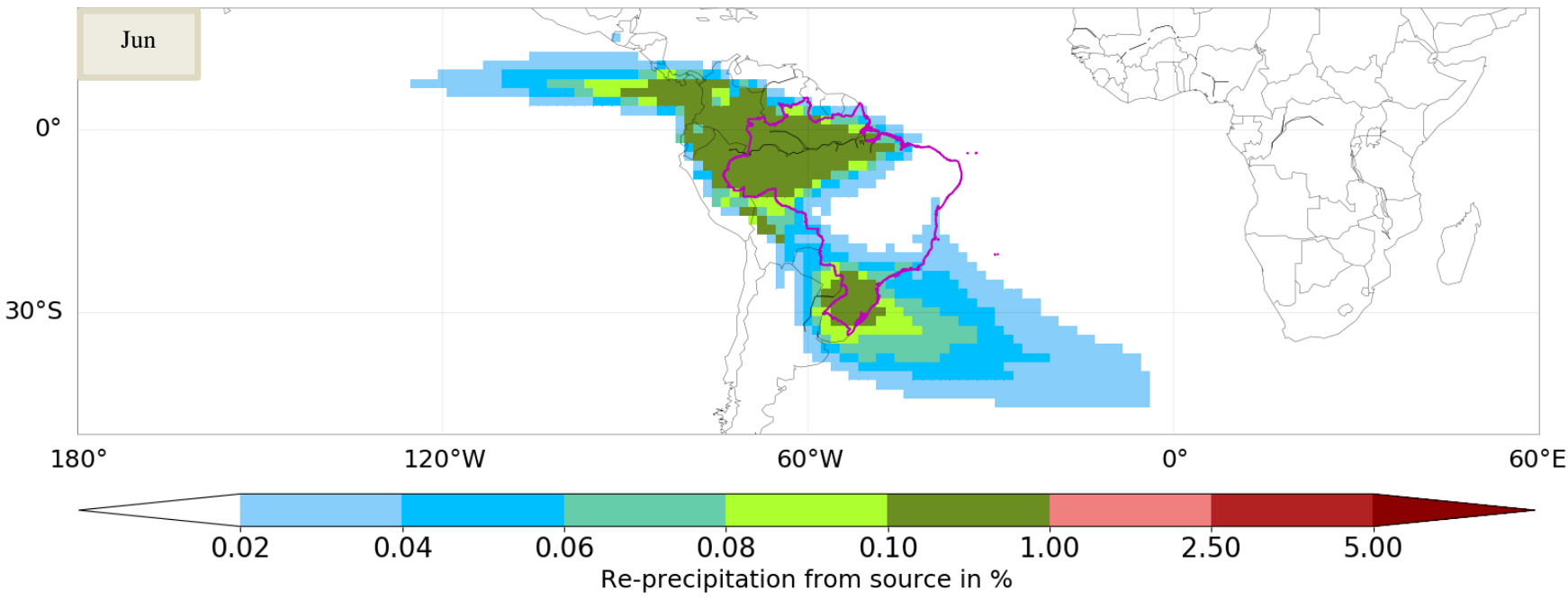

Figure S14 Monthly evaporationsheds $\left(A p r=\right.$ April, May, Jun = June) for Brazil $, E_{\text {input }}: 102.5 \mathrm{~mm} / \mathrm{month}($ Apr $) / 94.2 \mathrm{~mm} / \mathrm{month}$ 200 (May) / 85.3 mm/month (Jun), Unassigned : $0.1 \%$ (Apr) / $0.0 \%$ (May) / $0.1 \%$ (Jun), Colored area covers 82.9 \% (Apr) / $81.9 \%$ (May) / $78.7 \%$ (Jun) of the assigned water 

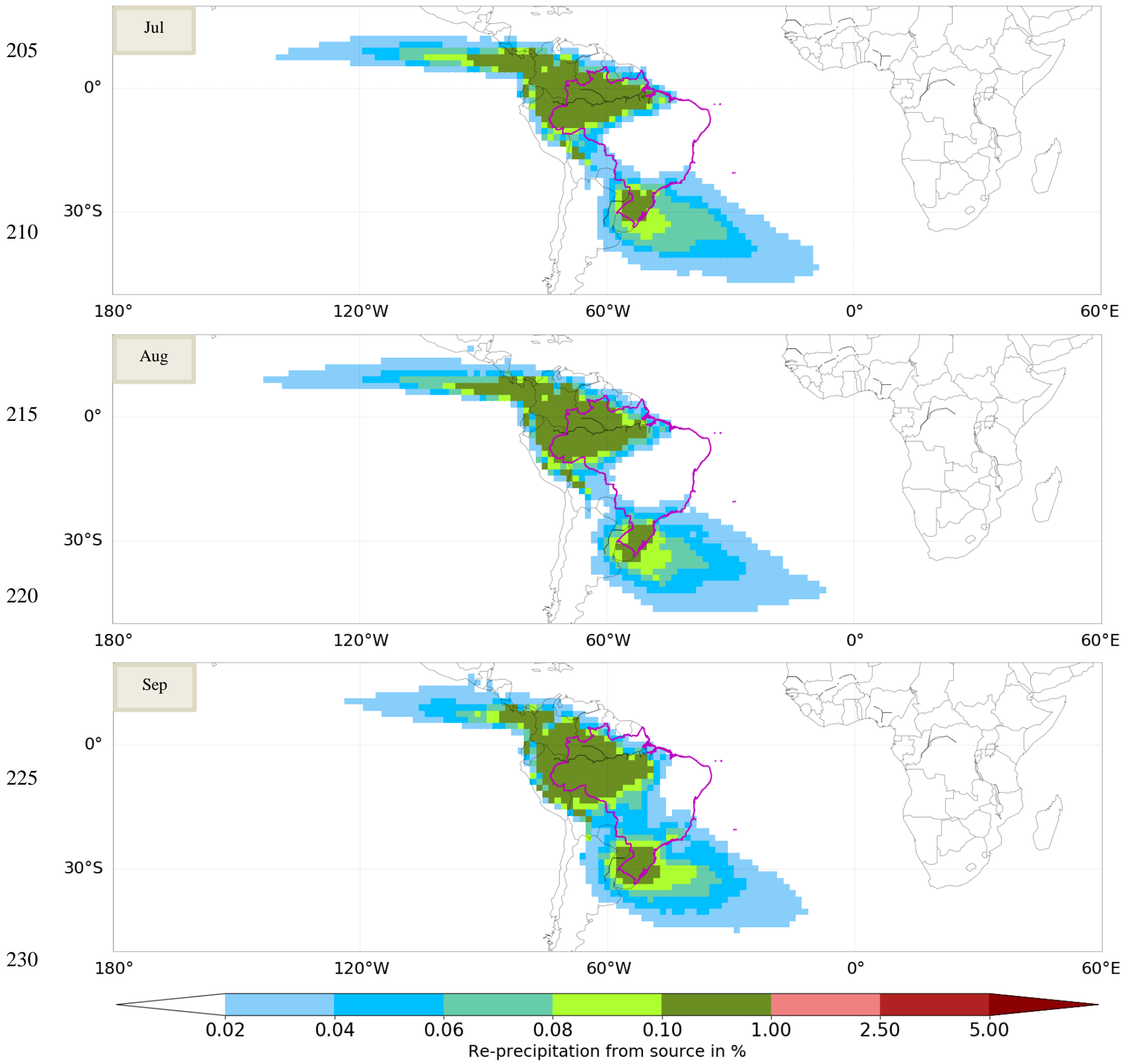

Figure S15 Monthly evaporationsheds (Jul = July, Aug = August, Sep = September $)$ for Brazil , $E_{\text {input }}: 86.2$ mm/month $(\mathrm{Jul}) / 90.8$ mm/month (Aug) / 97.0 mm/month (Sep), Unassigned : $0.1 \%$ (Jul) / $0.1 \%$ (Aug) / $0.1 \%$ (Sep), Colored area covers $76.8 \%$ (Jul) / 77.0 \% (Aug) / $78.7 \%$ (Sep) of the assigned water 

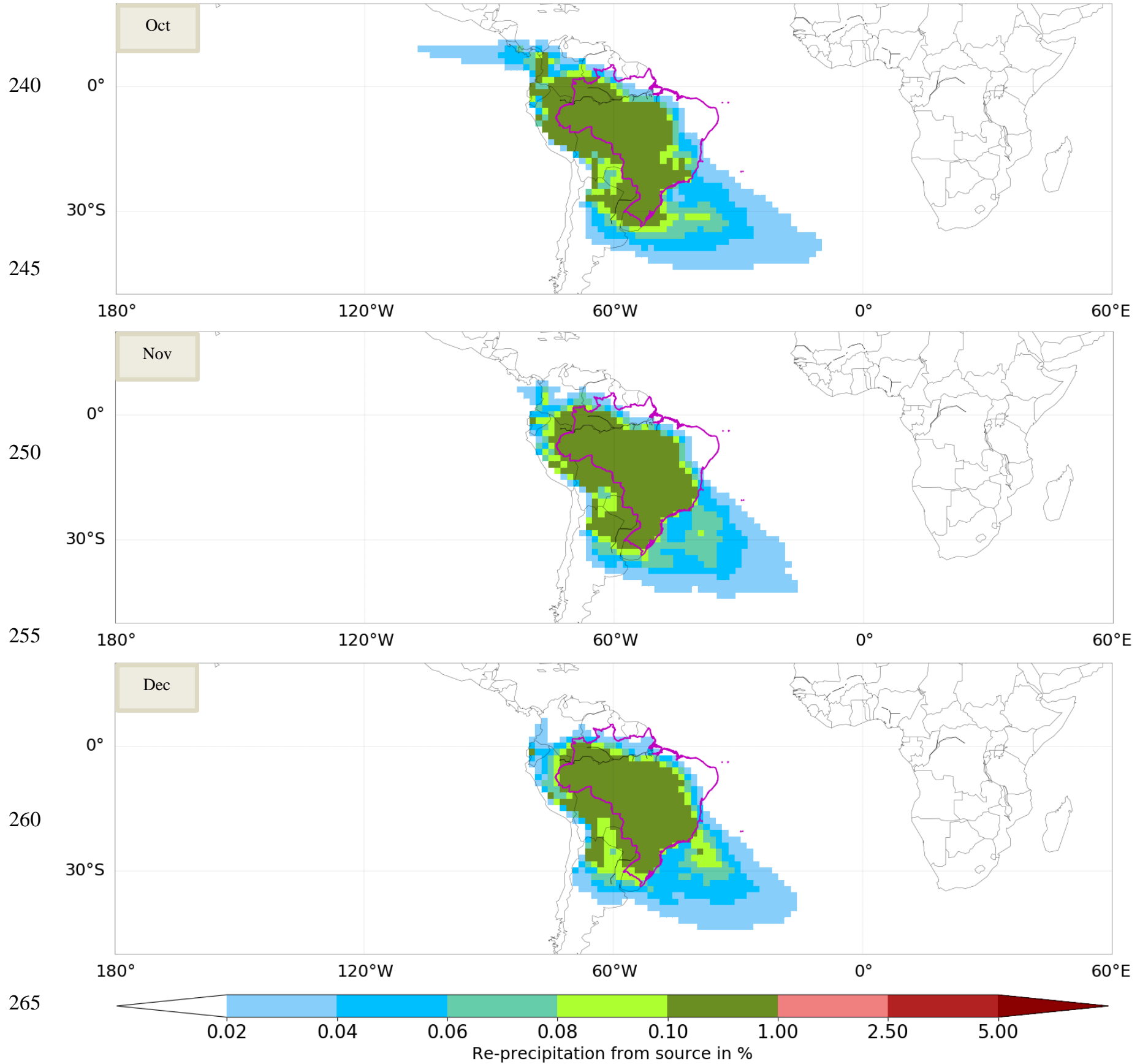

260

Figure S16 Monthly evaporationsheds $($ Oct $=$ October, Nov $=$ November, Dec $=$ December $)$ for Brazil $, E_{\text {input }}: 113.1 \mathrm{~mm} / \mathrm{month}($ Oct $)$ / $115.3 \mathrm{~mm} / \mathrm{month}$ (Nov) / $114.6 \mathrm{~mm} / \mathrm{month}$ (Dec), Unassigned : $0.1 \%$ (Oct) / $0.1 \%$ (Nov) / $0.1 \%$ (Dec), Colored area covers 81.2 $\%($ Oct) $/ 83.9 \%$ (Nov) / $84.3 \%$ (Dec) of the assigned water 

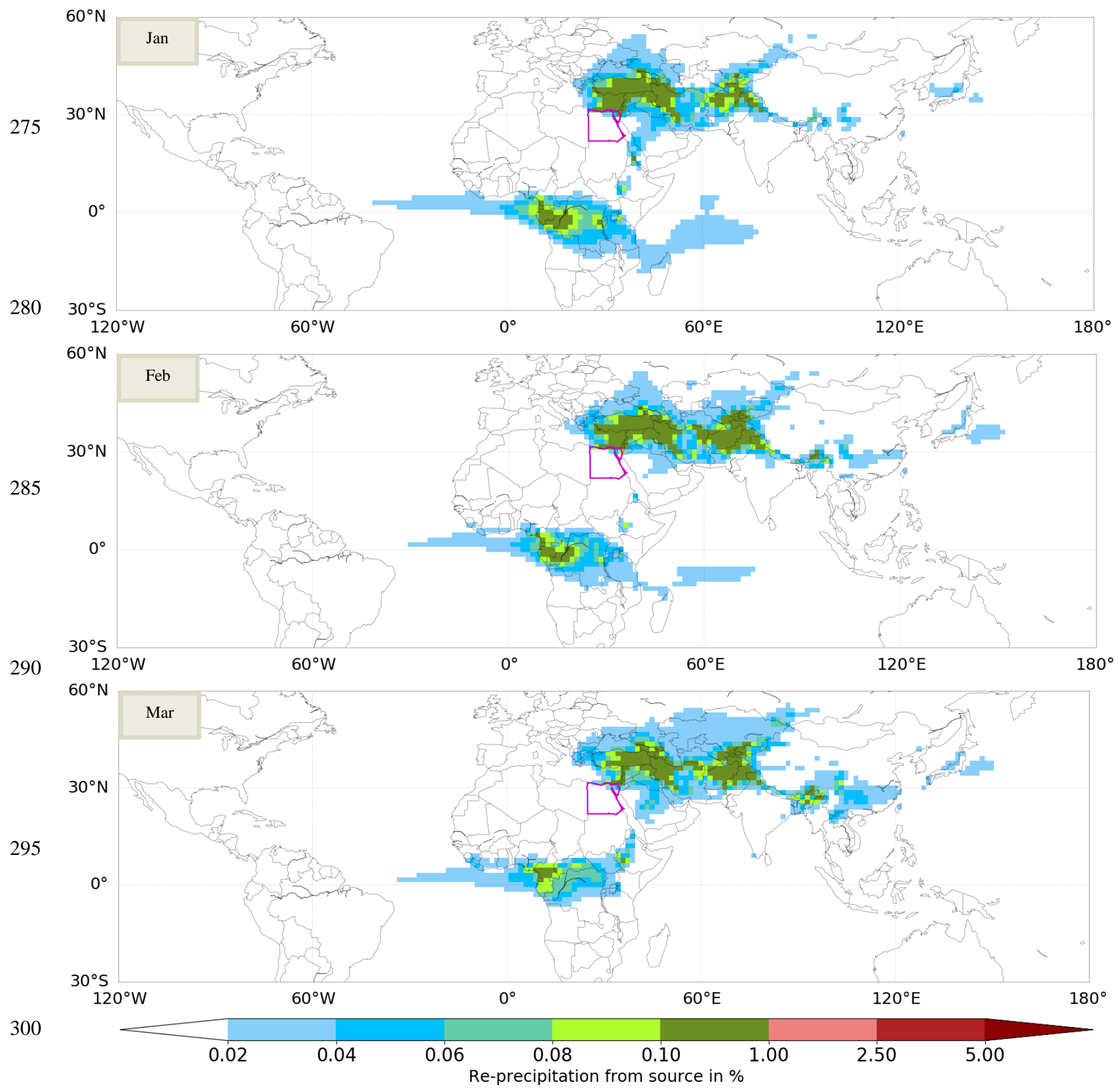

Figure S17 Monthly evaporationsheds $\left(\right.$ Jan = January, Feb = February, Mar = March) for Egypt $, E_{\text {input }}: 9.4 \mathrm{~mm} /$ month $($ Jan $) / 7.9$ mm/month (Feb) / 7.9 mm/month (Mar), Unassigned : $1.1 \%$ (Jan) / $0.8 \%$ (Feb) / $1.2 \%$ (Mar), Colored area covers $61.6 \%$ (Jan) / $61.3 \%$ (Feb) / 62.2\% (Mar) of the assigned water 


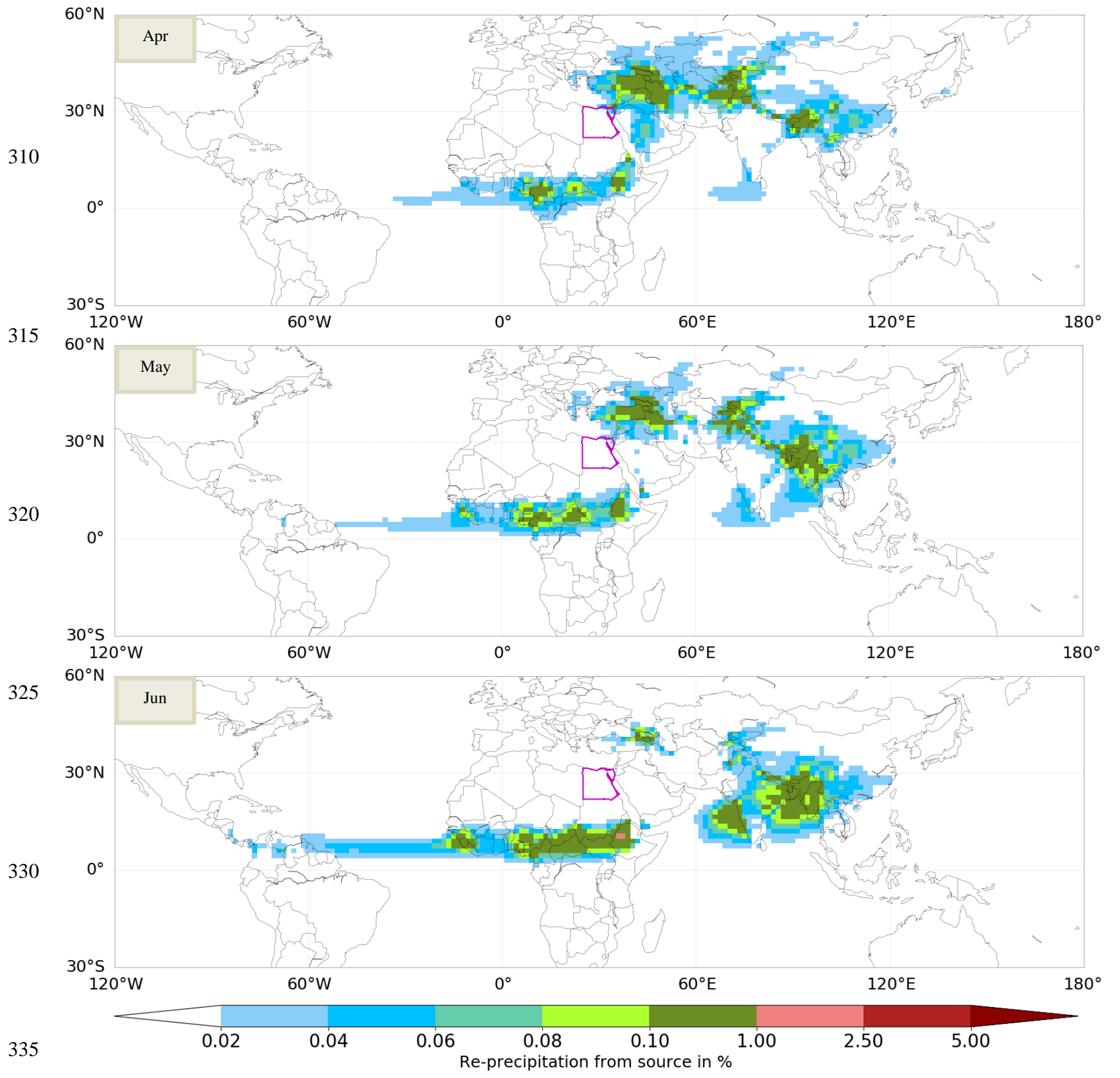

Figure S18 Monthly evaporationsheds $\left(\right.$ Apr = April, May, Jun = June) for Egypt , $E_{\text {input }}:$ 7.3 mm/month $($ Apr $) / 7.6 \mathrm{~mm} / \mathrm{month}(\mathrm{May})$ / 7.9 mm/month (Jun), Unassigned : $1.1 \%$ (Apr) / $0.9 \%$ (May) / 0.8 \% (Jun), Colored area covers 62.6 \% (Apr) / 65.0 \% (May) / $75.2 \%$ (Jun) of the assigned water 

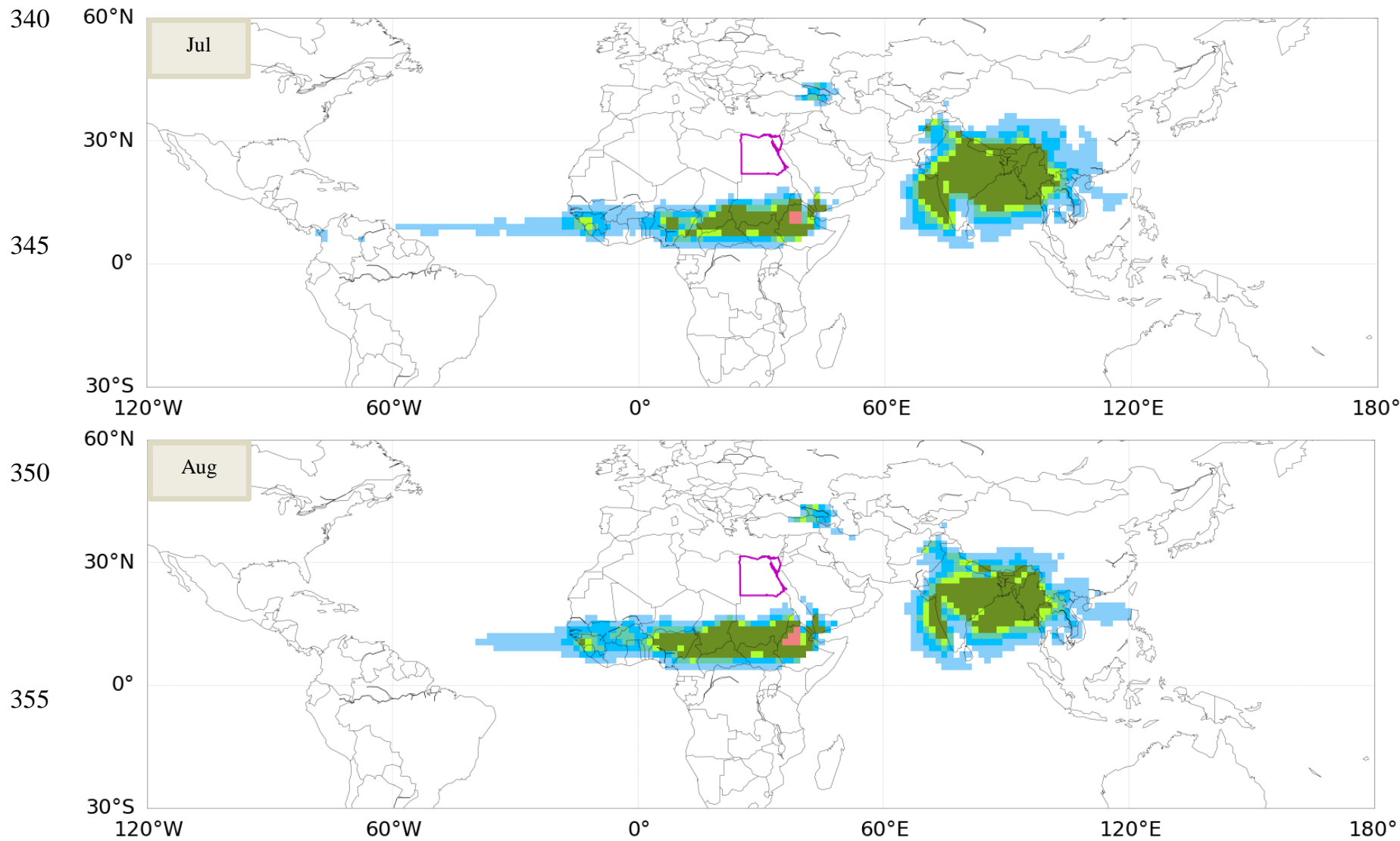

360

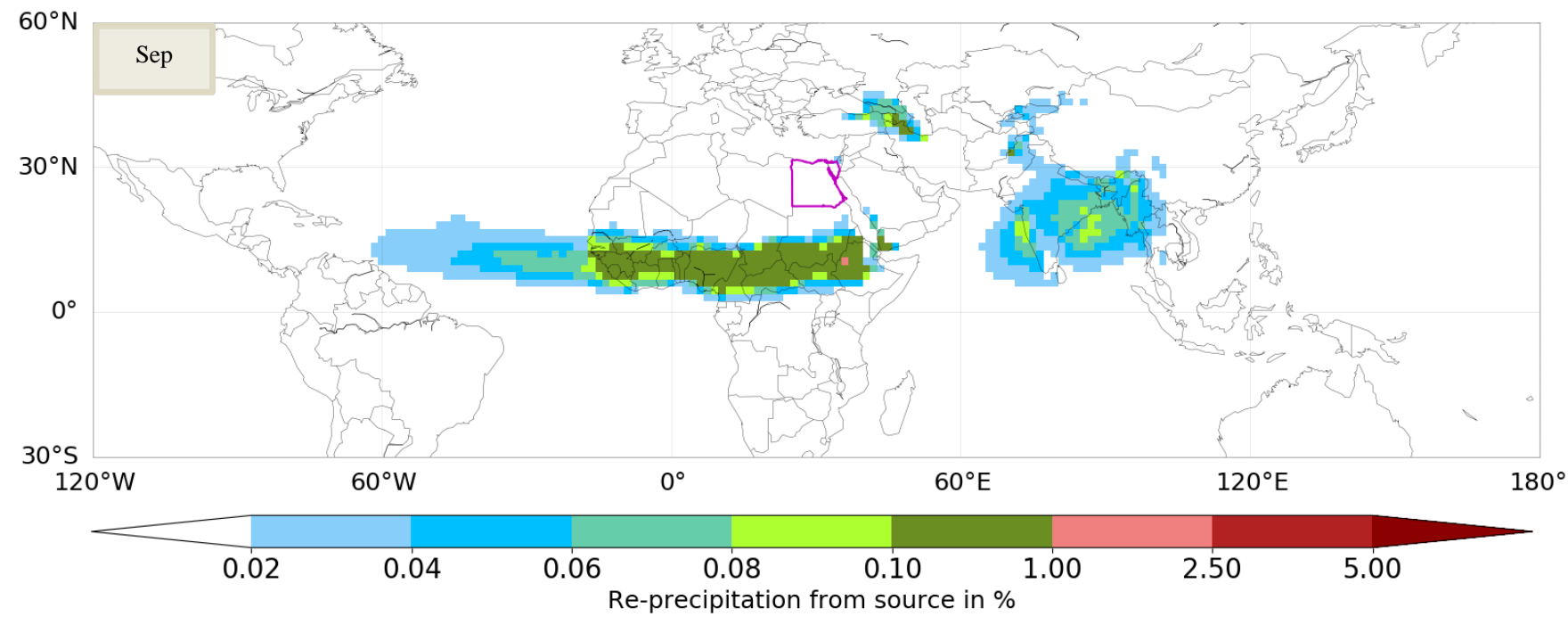

370 Figure S19 Monthly evaporationsheds (Jul = July, Aug = August, Sep = September) for Egypt , $E_{\text {input }}: 8.9$ mm/month $($ Jul $) / 9.5$ mm/month (Aug) / 9.6 mm/month (Sep), Unassigned : $0.3 \%$ (Jul) / $0.3 \%$ (Aug) / $0.5 \%$ (Sep), Colored area covers $80.2 \%$ (Jul) / $80.3 \%$ (Aug) / $74.1 \%$ (Sep) of the assigned water 
375

$60^{\circ} \mathrm{N}$
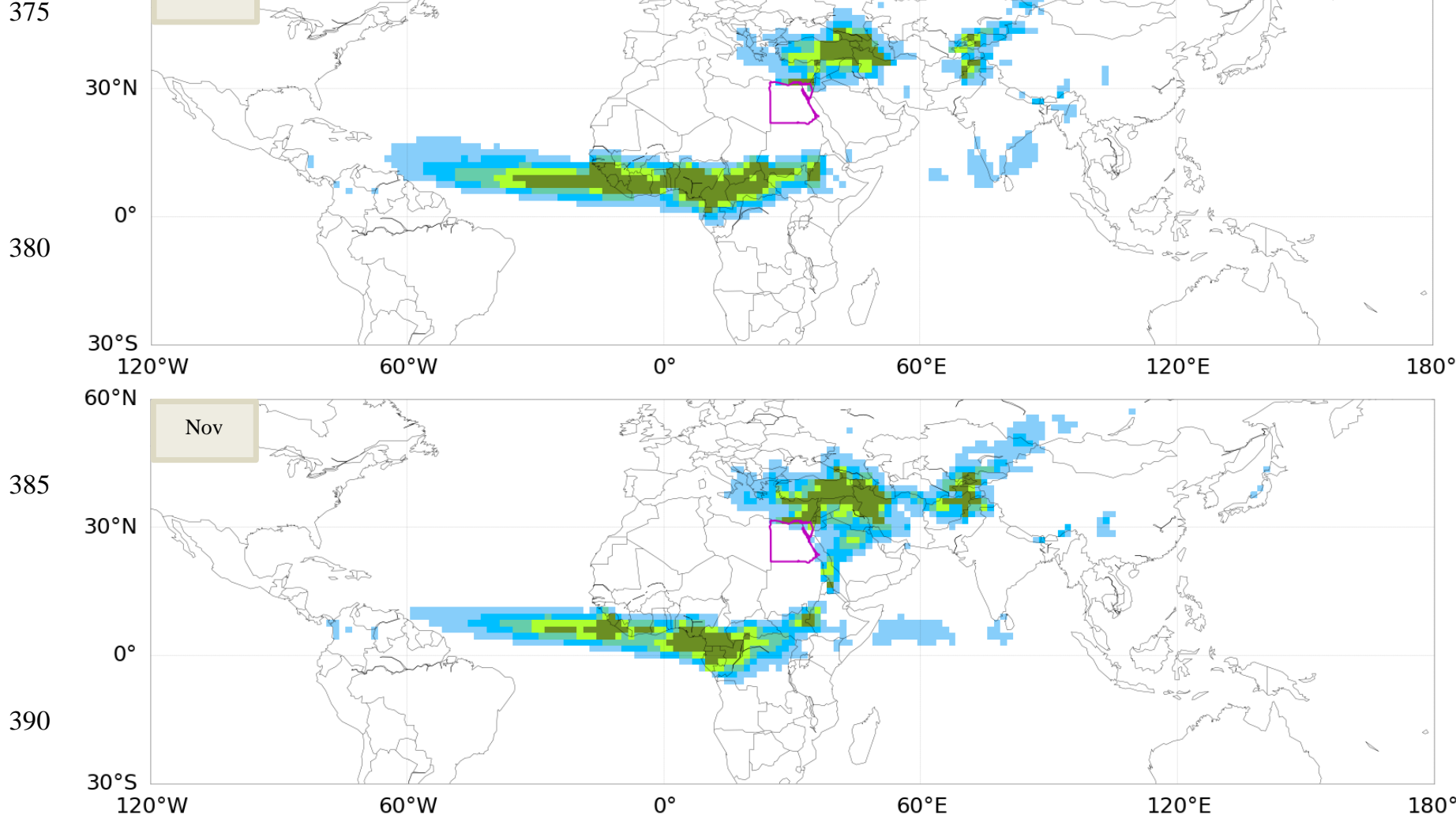

395

$60^{\circ} \mathrm{N}$

$120^{\circ} \mathrm{W} \quad 60^{\circ} \mathrm{W}$

400

$30^{\circ} \mathrm{S}$

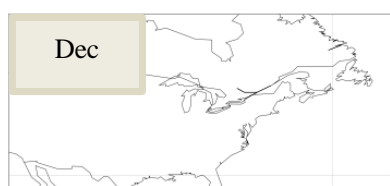

$30^{\circ} \mathrm{N}$

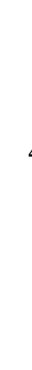

Figure S20 Monthly evaporationsheds $($ Oct $=$ October, Nov $=$ November, Dec $=$ December $)$ for Egypt $, E_{\text {input }}: 9.5 \mathrm{~mm} / \mathrm{month}($ Oct $) /$ $9.2 \mathrm{~mm} /$ month (Nov) / $9.5 \mathrm{~mm} / \mathrm{month}$ (Dec), Unassigned : $0.9 \%$ (Oct) / $1.0 \%$ (Nov) / $1.0 \%$ (Dec), Colored area covers $58.5 \%$ (Oct) / $59.1 \%$ (Nov) / $62.1 \%$ (Dec) of the assigned water 
$60^{\circ} \mathrm{N}$
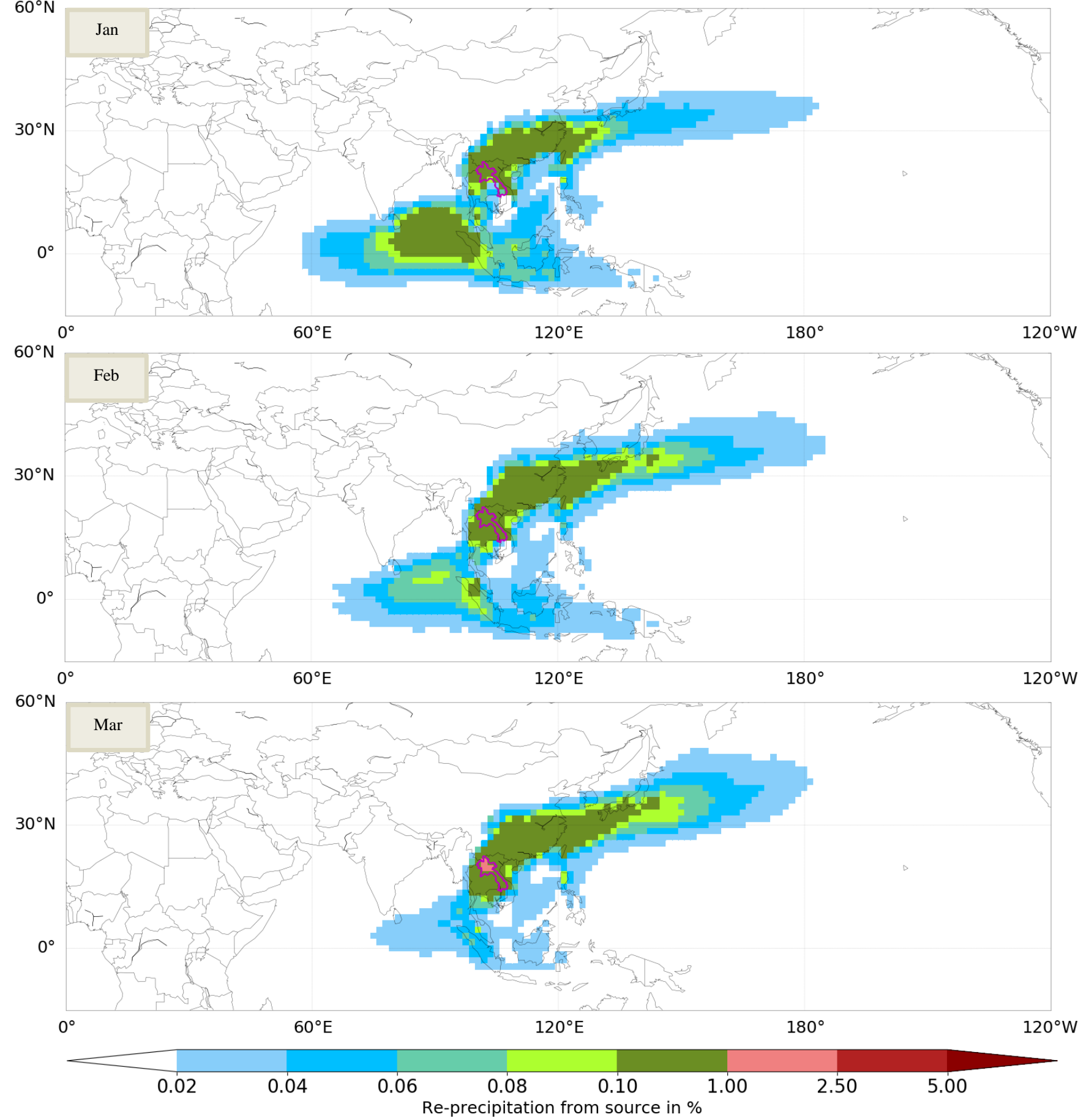

Figure S21 Monthly evaporationsheds $($ Jan $=$ January, Feb $=$ February, Mar $=$ March $)$ for Laos $, E_{\text {input }}: 67.0 \mathrm{~mm} / \mathrm{month}(\mathrm{Jan}) / 75.1$ 440 $\mathrm{mm} / \mathrm{month}$ (Feb) / $105.3 \mathrm{~mm} /$ month (Mar), Unassigned : $0.1 \%$ (Jan) / $0.1 \%$ (Feb) / $0.2 \%$ (Mar), Colored area covers $77.2 \%$ (Jan) / $76.3 \%$ (Feb) / $77.5 \%$ (Mar) of the assigned water 


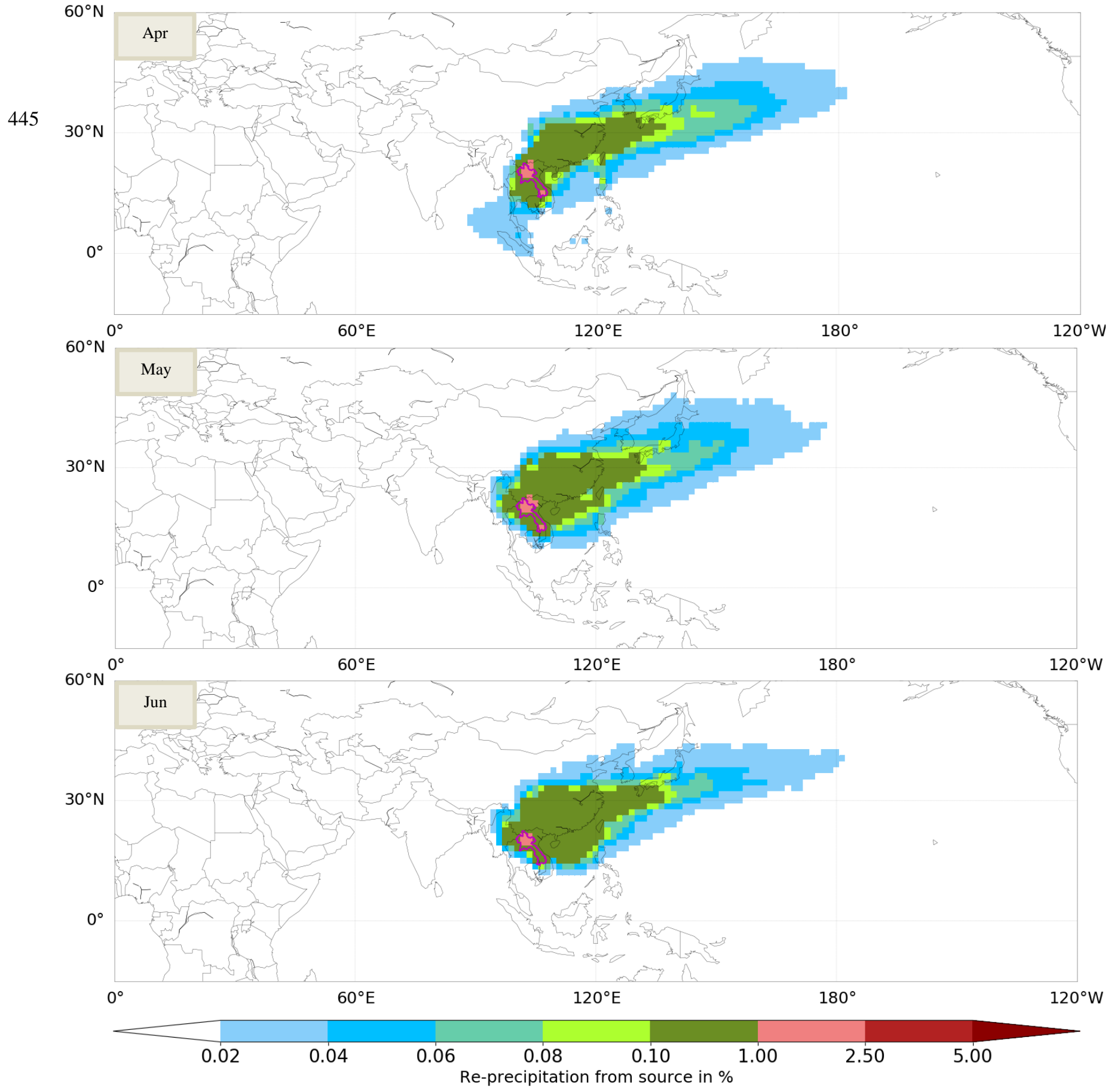

Figure S22 Monthly evaporationsheds $\left(\right.$ Apr = April, May, Jun = June) for Laos , $E_{\text {input }}: 123.3 \mathrm{~mm} / \mathrm{month}($ Apr $) / 123.1 \mathrm{~mm} / \mathrm{month}$ (May) / 112.7 mm/month (Jun), Unassigned : $0.3 \%$ (Apr) / $0.7 \%$ (May) / $0.6 \%$ (Jun), Colored area covers $80.3 \%$ (Apr) / $82.2 \%$ (May) / 82.1\% (Jun) of the assigned water 


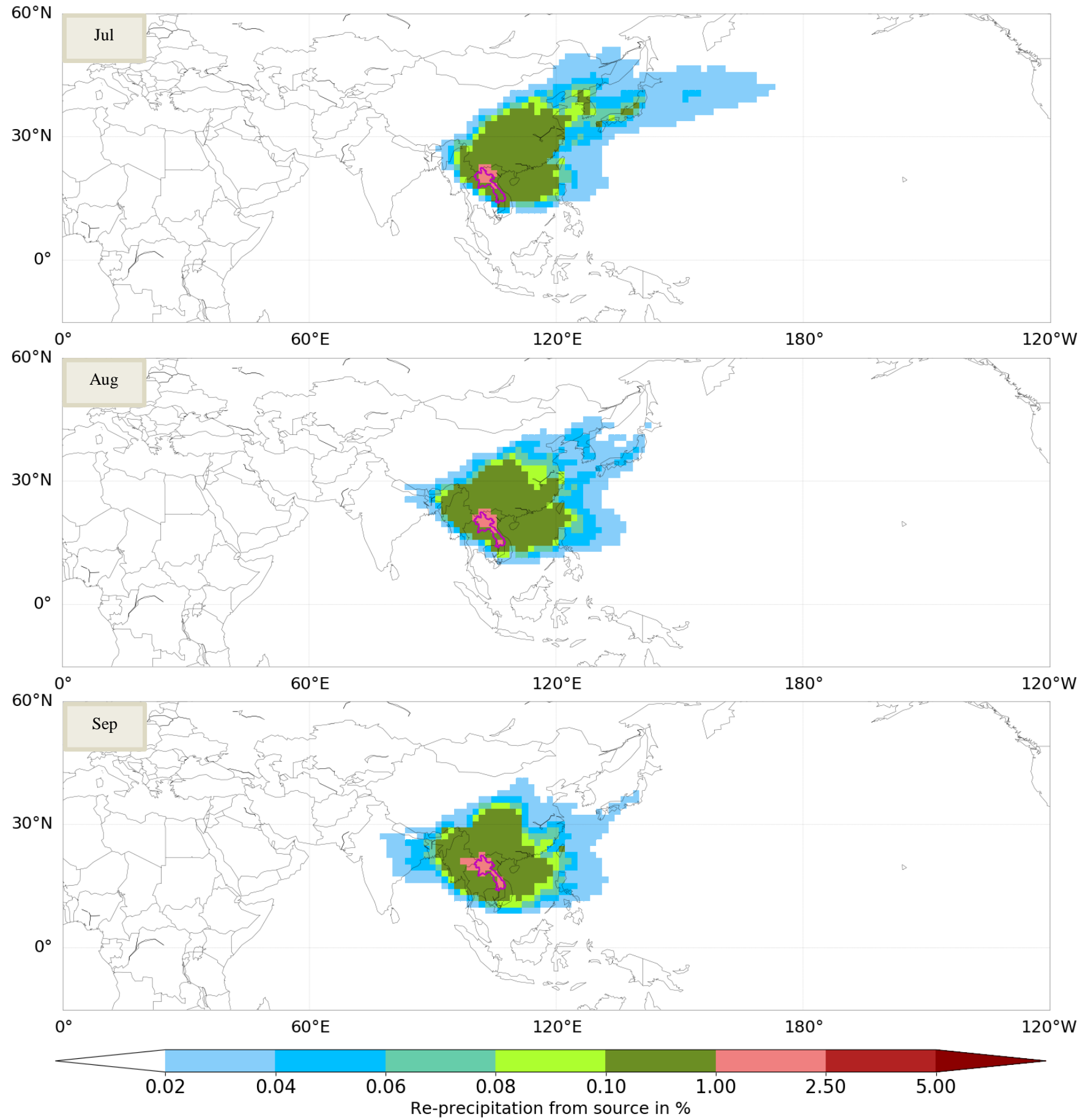

Figure S23 Monthly evaporationsheds $(J u l=$ July, Aug = August, Sep = September $)$ for Laos , $E_{\text {input }}: 106.0 \mathrm{~mm} / \mathrm{month}(\mathrm{Jul}) / 107.0$ mm/month (Aug) / 104.1 mm/month (Sep), Unassigned : $1.1 \%$ (Jul) / $0.6 \%$ (Aug) / $0.2 \%$ (Sep), Colored area covers $79.7 \%$ (Jul) / $82.8 \%$ (Aug) / 87.9 \% (Sep) of the assigned water 


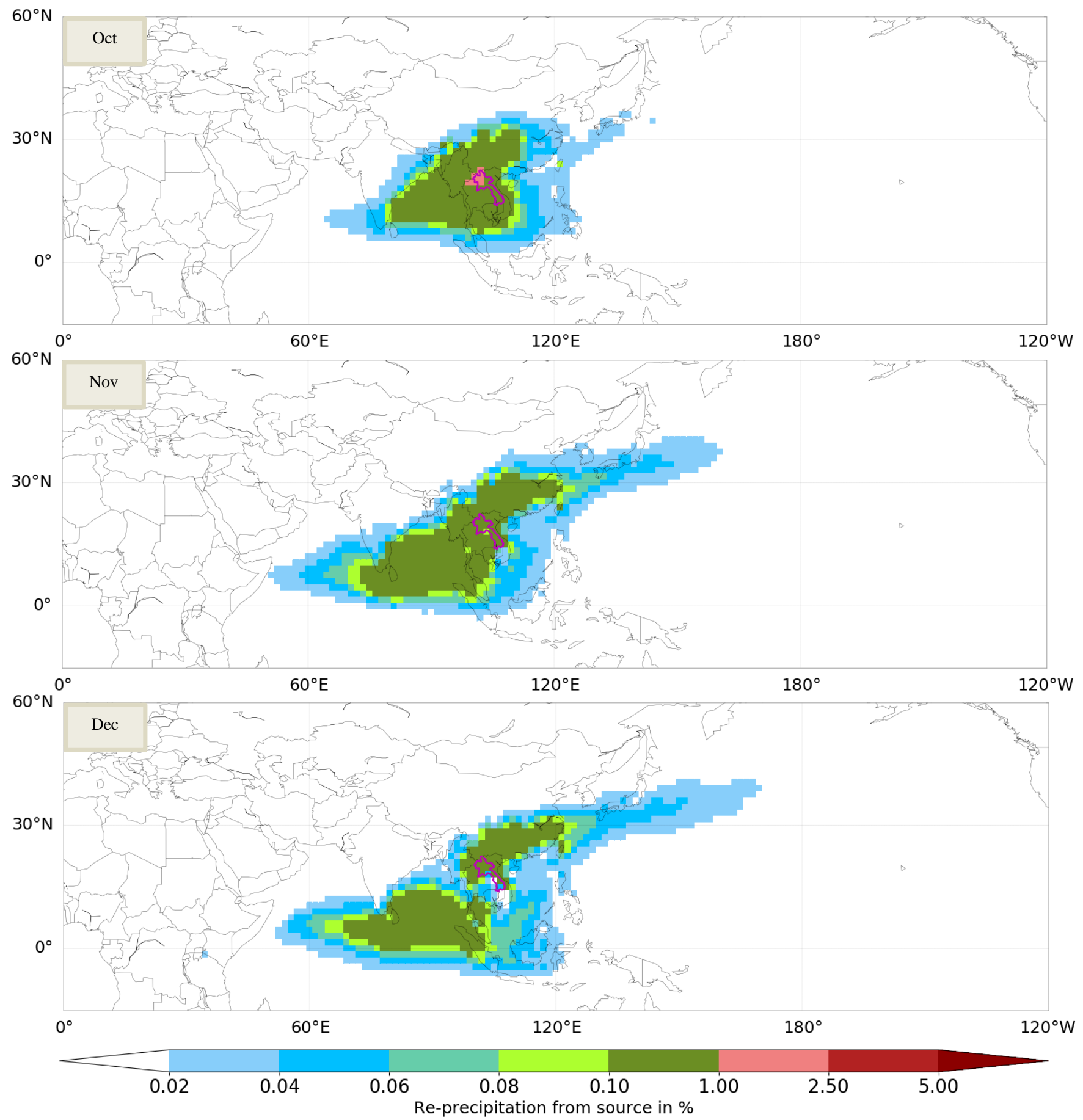

Figure S24 Monthly evaporationsheds $($ Oct $=$ October, Nov $=$ November, Dec $=$ December $)$ for Laos $, E_{\text {input }}: 105.0 \mathrm{~mm} / \mathrm{month}($ Oct $)$ / $84.6 \mathrm{~mm} / \mathrm{month}$ (Nov) / $65.8 \mathrm{~mm} / \mathrm{month}$ (Dec), Unassigned : $0.1 \%$ (Oct) / $0.1 \%$ (Nov) / 0.1 \% (Dec), Colored area covers $87.7 \%$ (Oct) $/ 84.6 \%$ (Nov) / 79.8 \% (Dec) of the assigned water 

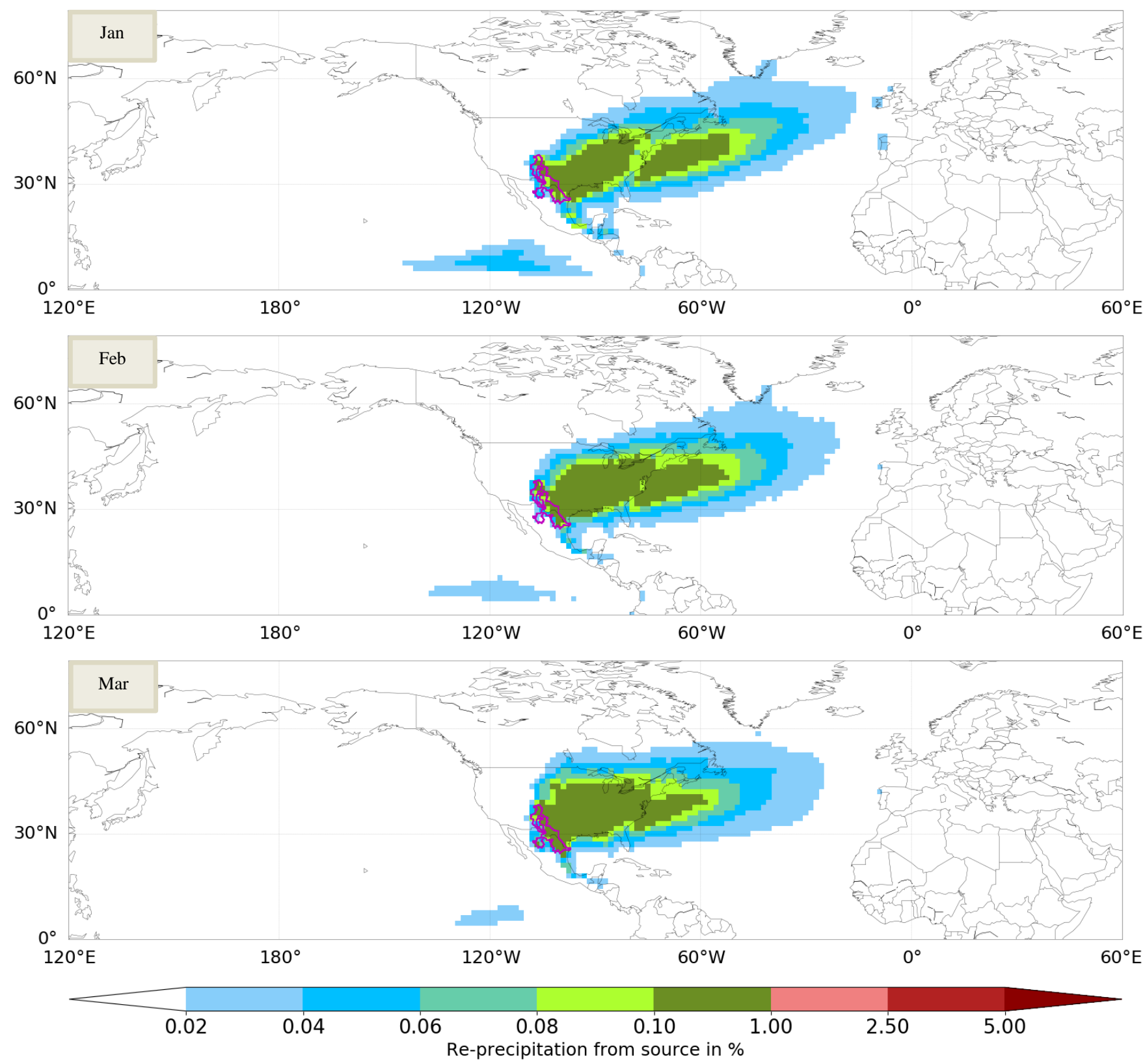

Figure S25 Monthly evaporationsheds (Jan = January, Feb = February, Mar = March) for the basin with the ID 1463188 (part of the Rio Grande basin), $E_{\text {input }}: 19.5 \mathrm{~mm} / \mathrm{month}$ (Jan) / $21.9 \mathrm{~mm} / \mathrm{month}$ (Feb) / $32.9 \mathrm{~mm} / \mathrm{month}$ (Mar), Unassigned : $0.8 \%$ (Jan) / 0.7 \% (Feb) / $0.6 \%$ (Mar), Colored area covers $73.6 \%$ (Jan) / $74.4 \%$ (Feb) / 74.0 \% (Mar) of the assigned water 

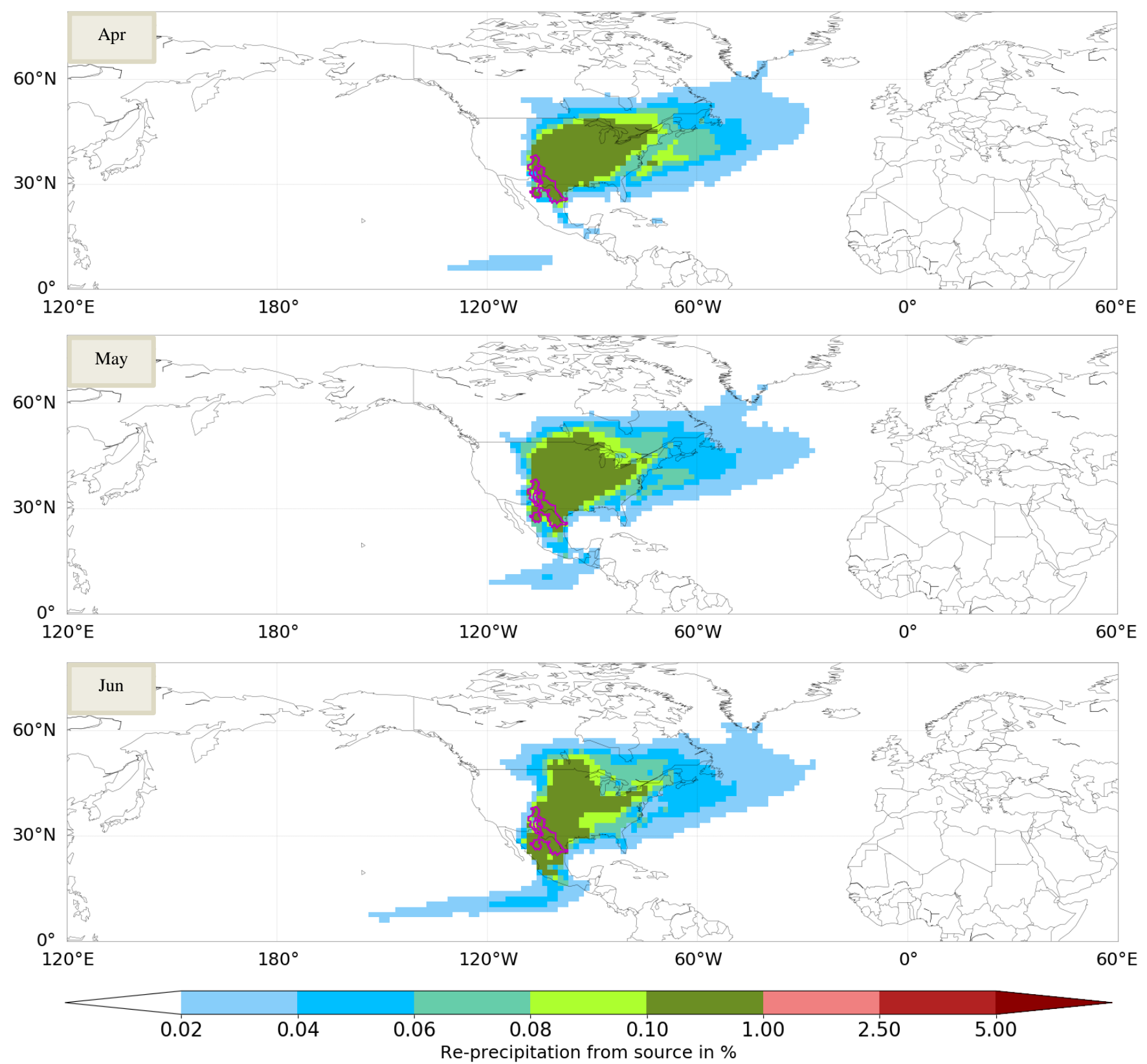

Figure S26 Monthly evaporationsheds (Apr = April, May, Jun = June) for the basin with the ID 1463188 (part of the Rio Grande basin), $E_{\text {input }}: 40.7$ mm/month (Apr) / 52.3 mm/month (May) / 50.1 mm/month (Jun), Unassigned : $0.9 \%$ (Apr) / $1.1 \%$ (May) / 1.7 \% (Jun), Colored area covers 74.6 \% (Apr) / 76.4 \% (May) / 73.1 \% (Jun) of the assigned water 

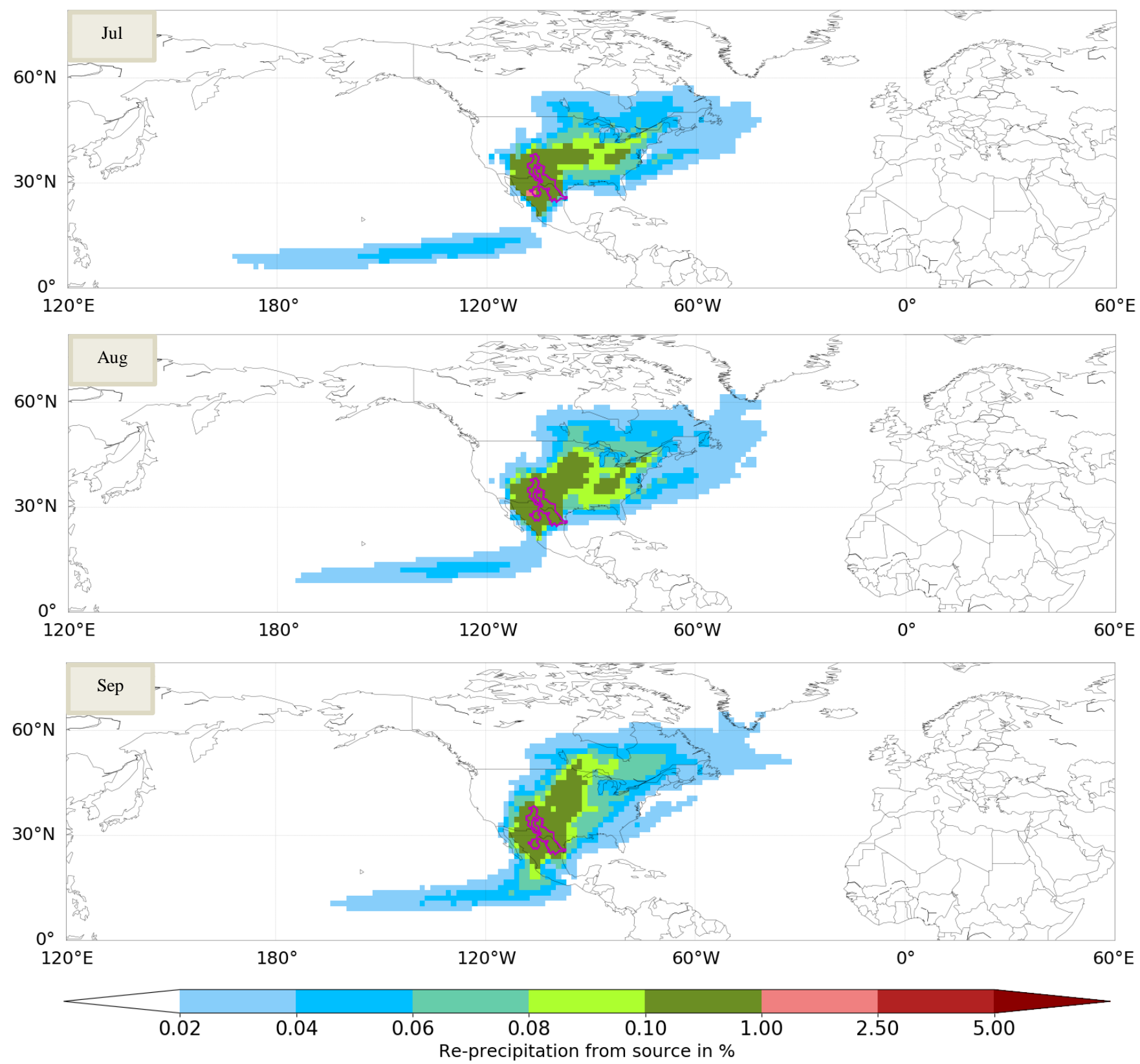

Figure S27 Monthly evaporationsheds (Jul = July, Aug = August, Sep = September) for the basin with the ID 1463188 (part of the Rio Grande basin), $E_{\text {input }}: 67.1 \mathrm{~mm} / \mathrm{month}$ (Jul) / $64.7 \mathrm{~mm} / \mathrm{month}$ (Aug) / $60.5 \mathrm{~mm} / \mathrm{month}$ (Sep), Unassigned : $1.5 \%$ (Jul) / $1.5 \%$ (Aug) / $1.6 \%$ (Sep), Colored area covers $69.1 \%$ (Jul) / $69.7 \%$ (Aug) / $69.9 \%$ (Sep) of the assigned water 

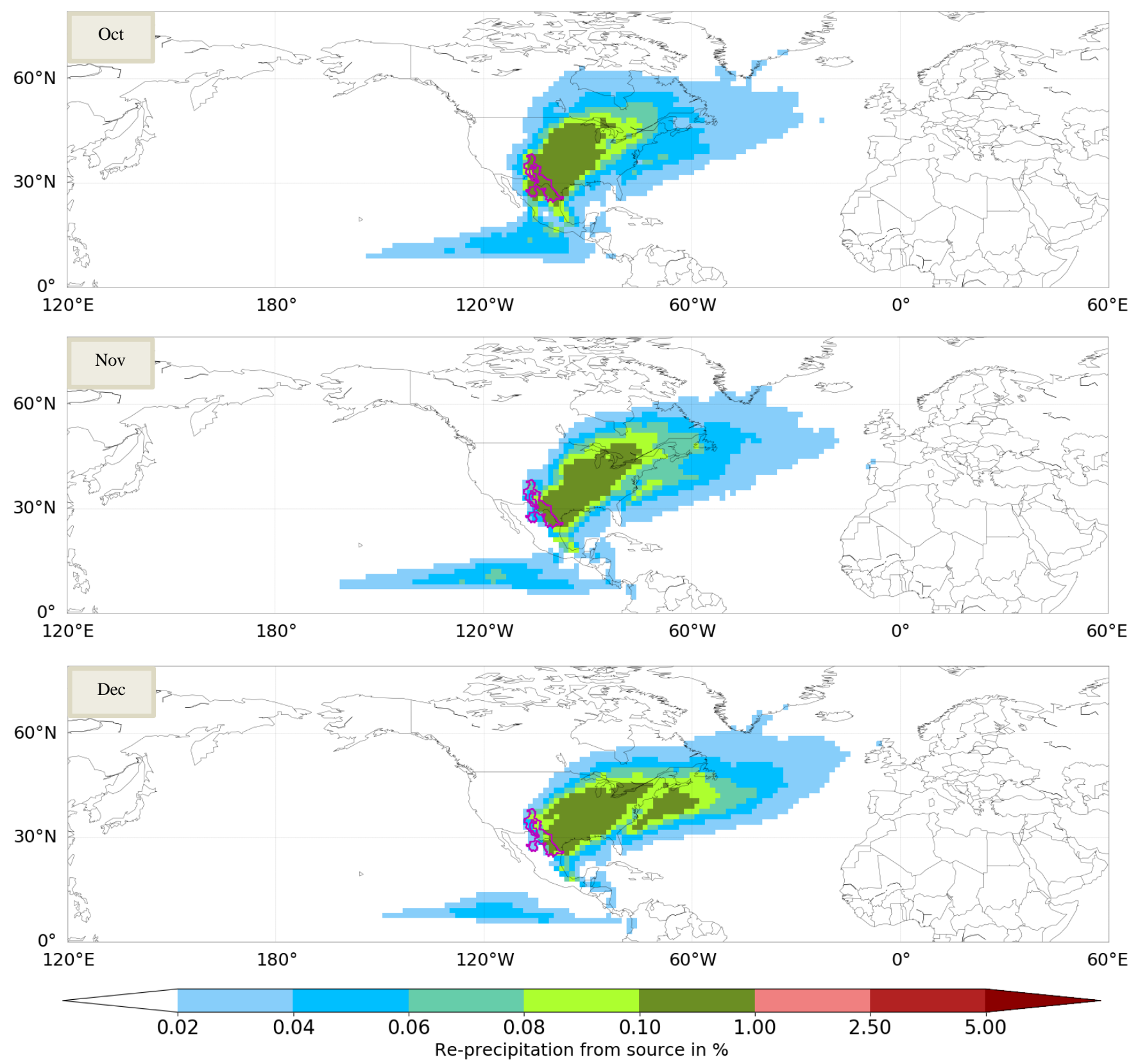

Figure S28 Monthly evaporationsheds (Oct $=$ October, Nov = November, Dec $=$ December) for the basin with the ID 1463188 (part of the Rio Grande basin), $E_{\text {input }}: 47.1 \mathrm{~mm} / \mathrm{month}($ Oct) / $26.1 \mathrm{~mm} / \mathrm{month}$ (Nov) / $19.6 \mathrm{~mm} / \mathrm{month}$ (Dec), Unassigned : $1.6 \%$ (Oct) / $1.0 \%$ (Nov) / $0.8 \%$ (Dec), Colored area covers $71.3 \%$ (Oct) / $71.2 \%$ (Nov) / $73.1 \%$ (Dec) of the assigned water 


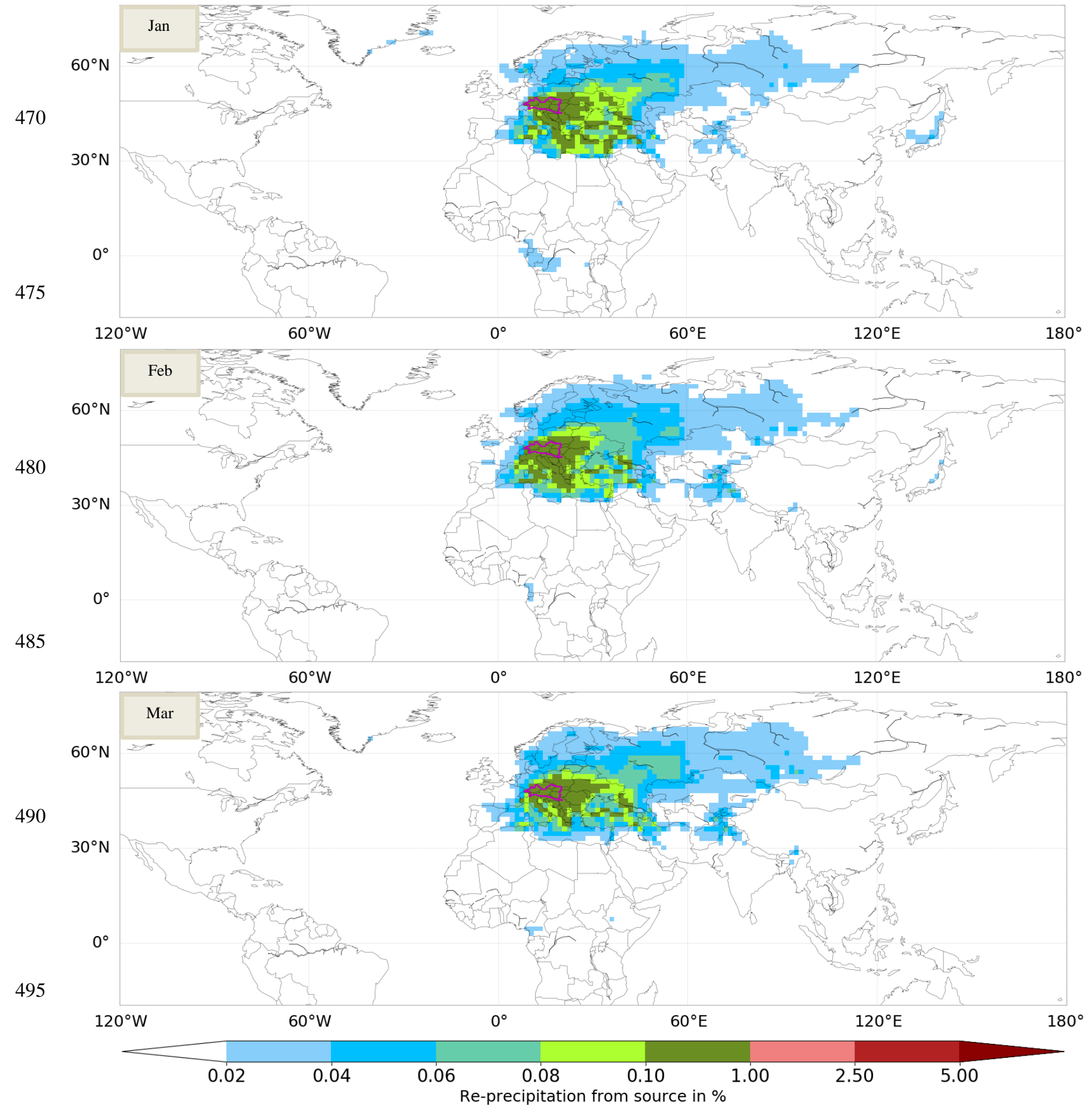

Figure S29 Monthly evaporationsheds (Jan = January, Feb = February, Mar = March) for the basin with the ID 1019324 (part of the Danube basin), $E_{\text {input }}: \mathbf{1 0 . 4} \mathrm{mm} / \mathrm{month}(\mathrm{Jan}) / 15.9 \mathrm{~mm} / \mathrm{month}($ Feb) / $36.2 \mathrm{~mm} / \mathrm{month}$ (Mar), Unassigned : $3.7 \%$ (Jan) / $3.8 \%$ (Feb) / $3.4 \%$ (Mar), Colored area covers $65.4 \%$ (Jan) / $68.0 \%$ (Feb) / $68.8 \%$ (Mar) of the assigned water 


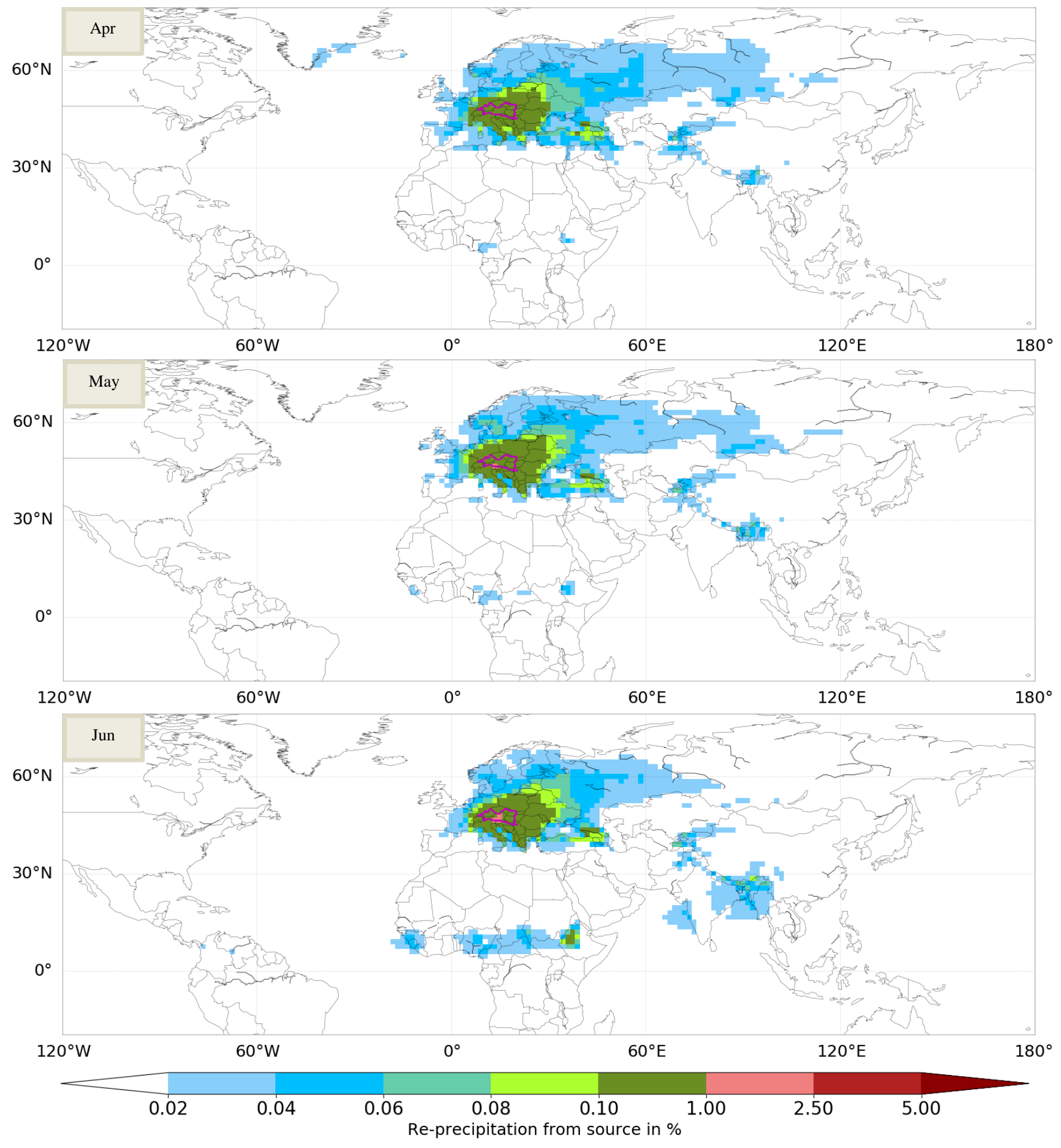

500 Figure S30 Monthly evaporationsheds (Apr = April, May, Jun = June) for the basin with the ID 1019324 (part of the Danube basin), $E_{\text {input }}: 61.6 \mathrm{~mm} /$ month (Apr) / $87.7 \mathrm{~mm} / \mathrm{month}$ (May) $/ 99.3 \mathrm{~mm} / \mathrm{month}$ (Jun), Unassigned : $4.6 \%$ (Apr) / $3.6 \%$ (May) / $3.6 \%$ (Jun), Colored area covers $66.4 \%$ (Apr) / $65.8 \%$ (May) / $69.3 \%$ (Jun) of the assigned water 


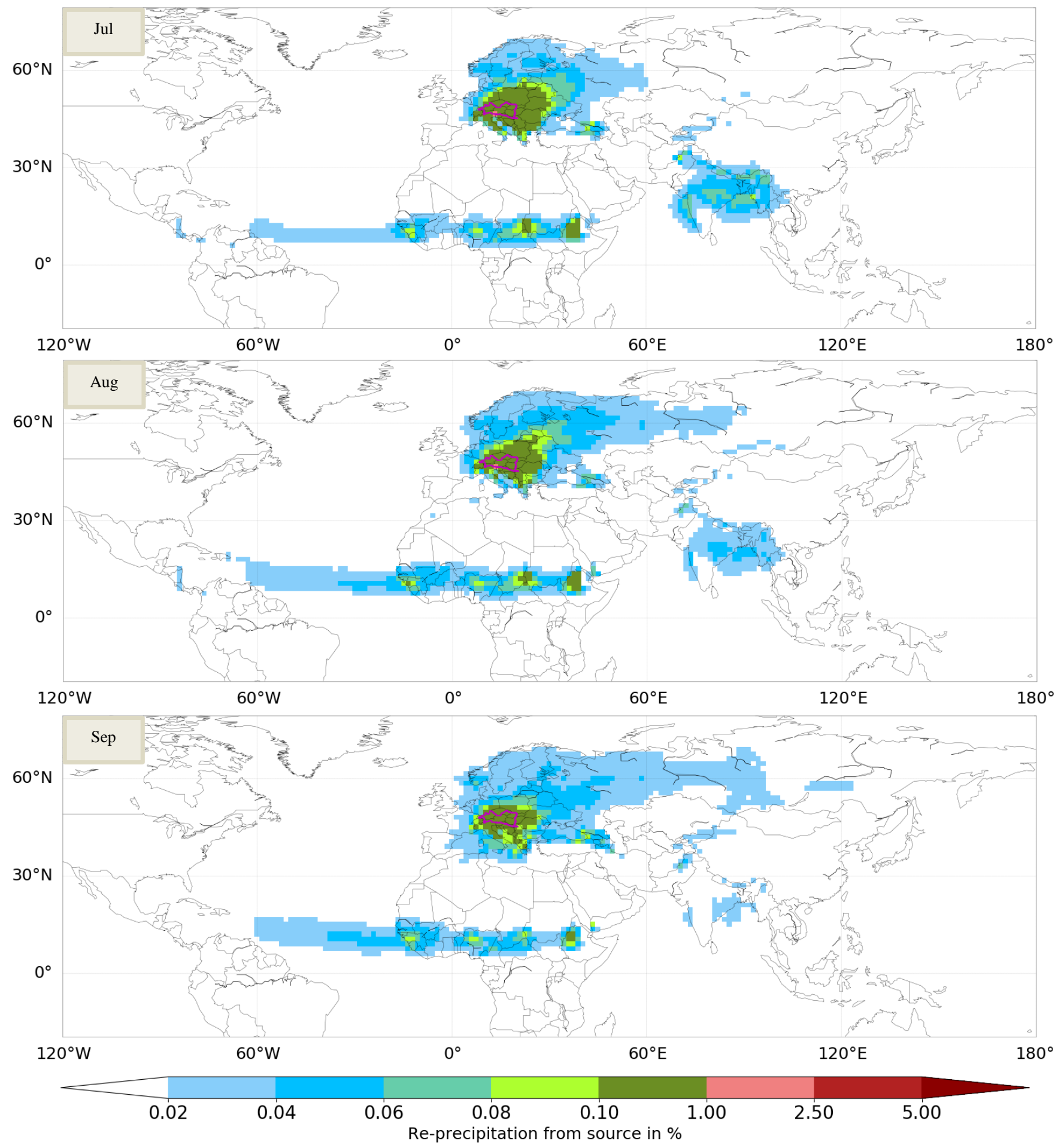

Figure S31 Monthly evaporationsheds (Jul = July, Aug = August, Sep = September) for the basin with the ID 1019324 (part of the Danube basin), $E_{\text {input }}: \mathbf{1 0 3 . 0 ~ m m} / \mathrm{month}(\mathrm{Jul}) / 85.7 \mathrm{~mm} / \mathrm{month}$ (Aug) / $53.2 \mathrm{~mm} / \mathrm{month}$ (Sep), Unassigned : $3.5 \%$ (Jul) / $3.8 \%$ (Aug) / $6.0 \%$ (Sep), Colored area covers $69.5 \%$ (Jul) / $66.5 \%$ (Aug) / $59.6 \%$ (Sep) of the assigned water 


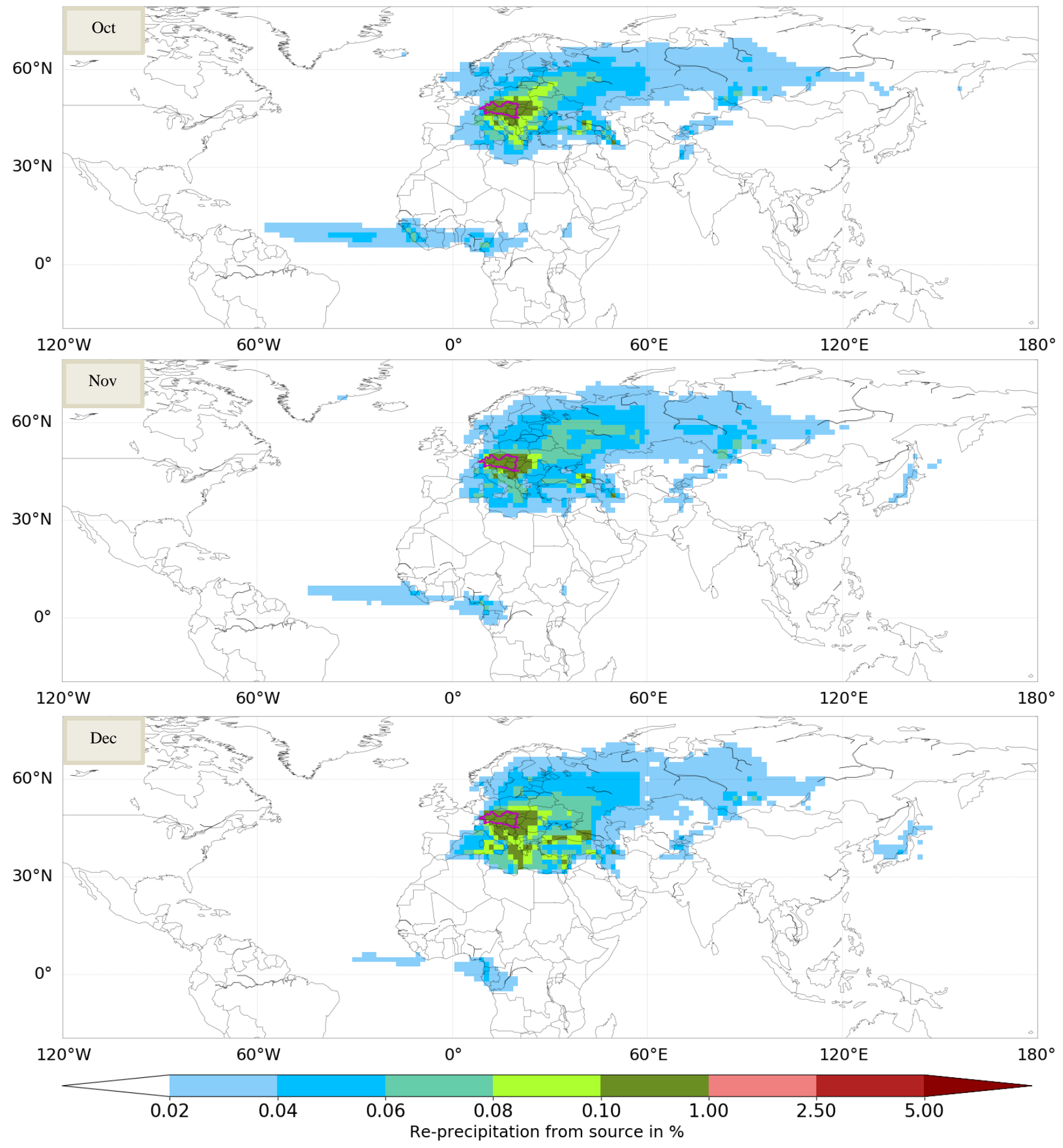

Figure S32 Monthly evaporationsheds $($ Oct $=$ October, Nov = November, Dec $=$ December) for the basin with the ID $1019324($ part of the Danube basin), $E_{\text {input }}: 31.5 \mathrm{~mm} / \mathrm{month}$ (Oct) / $15.5 \mathrm{~mm} / \mathrm{month}$ (Nov) / $9.5 \mathrm{~mm} / \mathrm{month}$ (Dec), Unassigned : $4.2 \%$ (Oct) / $4.3 \%$ (Nov) / $4.0 \%$ (Dec), Colored area covers $55.6 \%$ (Oct) / $57.8 \%$ (Nov) / 62.2 \% (Dec) of the assigned water 


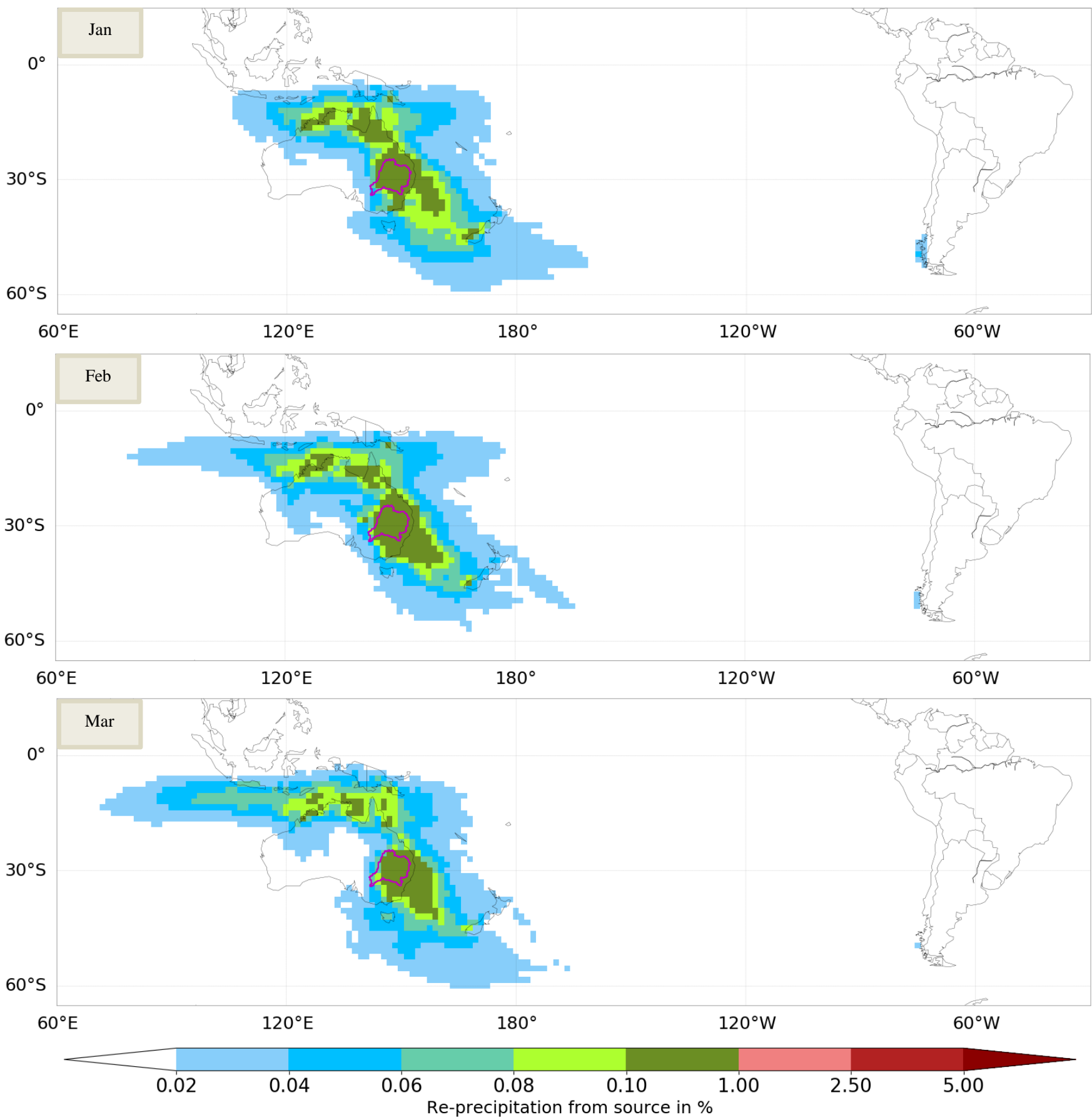

Figure S33 Monthly evaporationsheds (Jan = January, Feb = February, Mar = March) for the basin with the ID 2245569 (part of the Murray-Darling basin), $E_{\text {input }}: 67.3 \mathrm{~mm} / \mathrm{month}(\mathrm{Jan}) / 58.0 \mathrm{~mm} / \mathrm{month}($ Feb) $/ 50.2 \mathrm{~mm} / \mathrm{month}$ (Mar), Unassigned : 0.6 \% (Jan) / $0.4 \%$ (Feb) / $0.5 \%$ (Mar), Colored area covers $62.8 \%$ (Jan) / $63.5 \%$ (Feb) / 62.7 \% (Mar) of the assigned water 


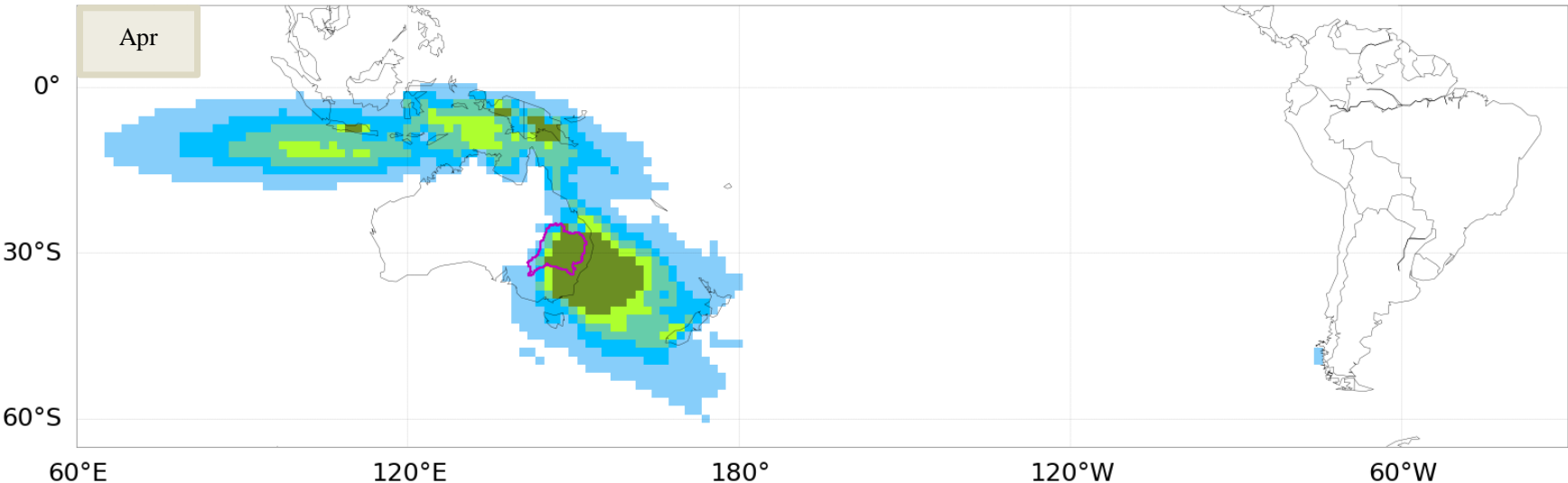

$60^{\circ} \mathrm{S}$

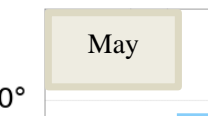

$180^{\circ}$

$120^{\circ} \mathrm{W}$

$60^{\circ} \mathrm{W}$

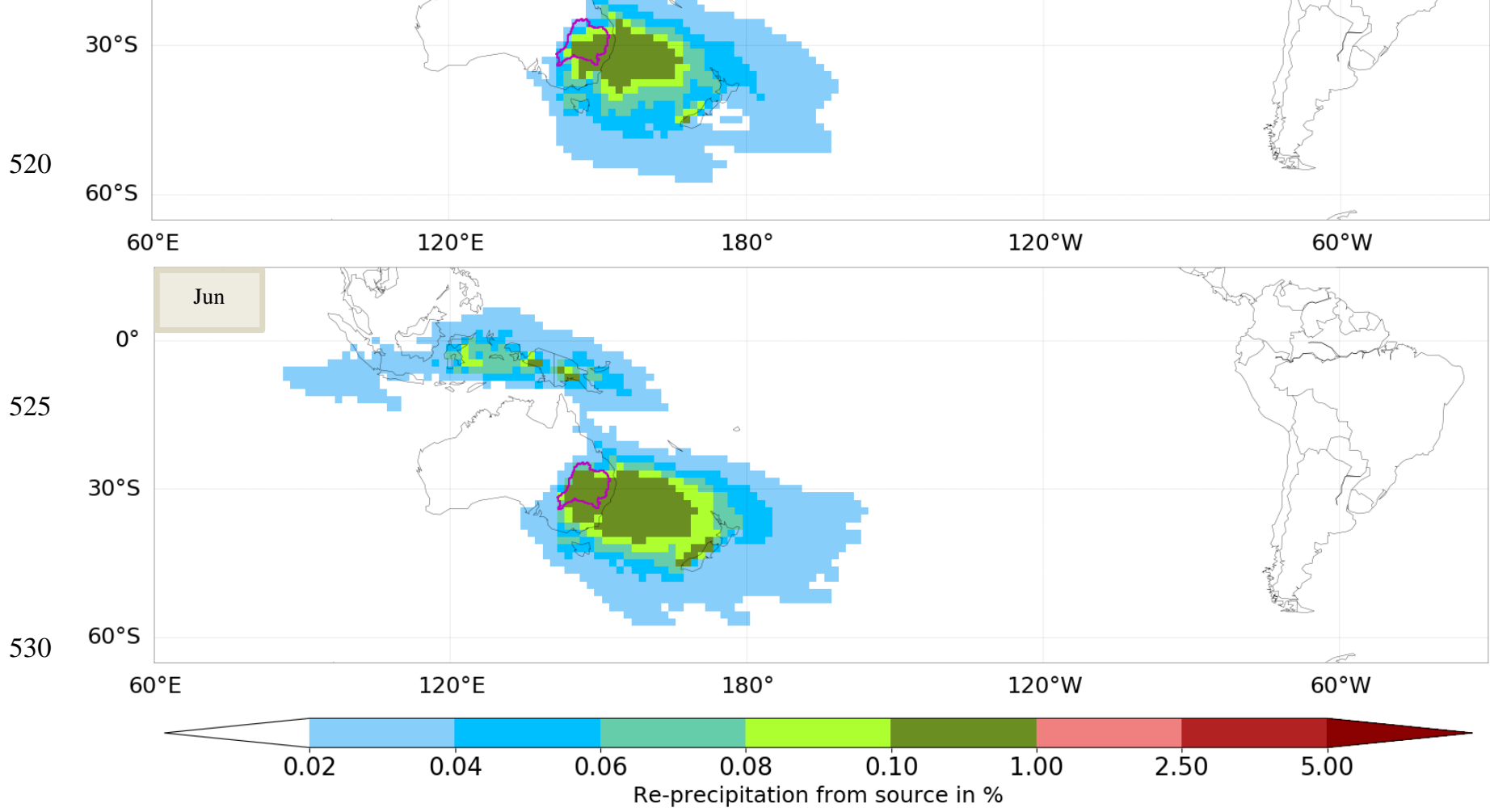

Figure S34 Monthly evaporationsheds (Apr = April, May, Jun = June) for the basin with the ID 2245569 (part of the Murray-Darling basin), $E_{\text {input }}: 30.0$ mm/month (Apr) / 21.6 mm/month (May) / 21.9 mm/month (Jun), Unassigned : $0.5 \%$ (Apr) / $0.5 \%$ (May) / 0.5 $\%$ (Jun), Colored area covers $59.9 \%$ (Apr) / $61.4 \%$ (May) / 60.8 \% (Jun) of the assigned water 


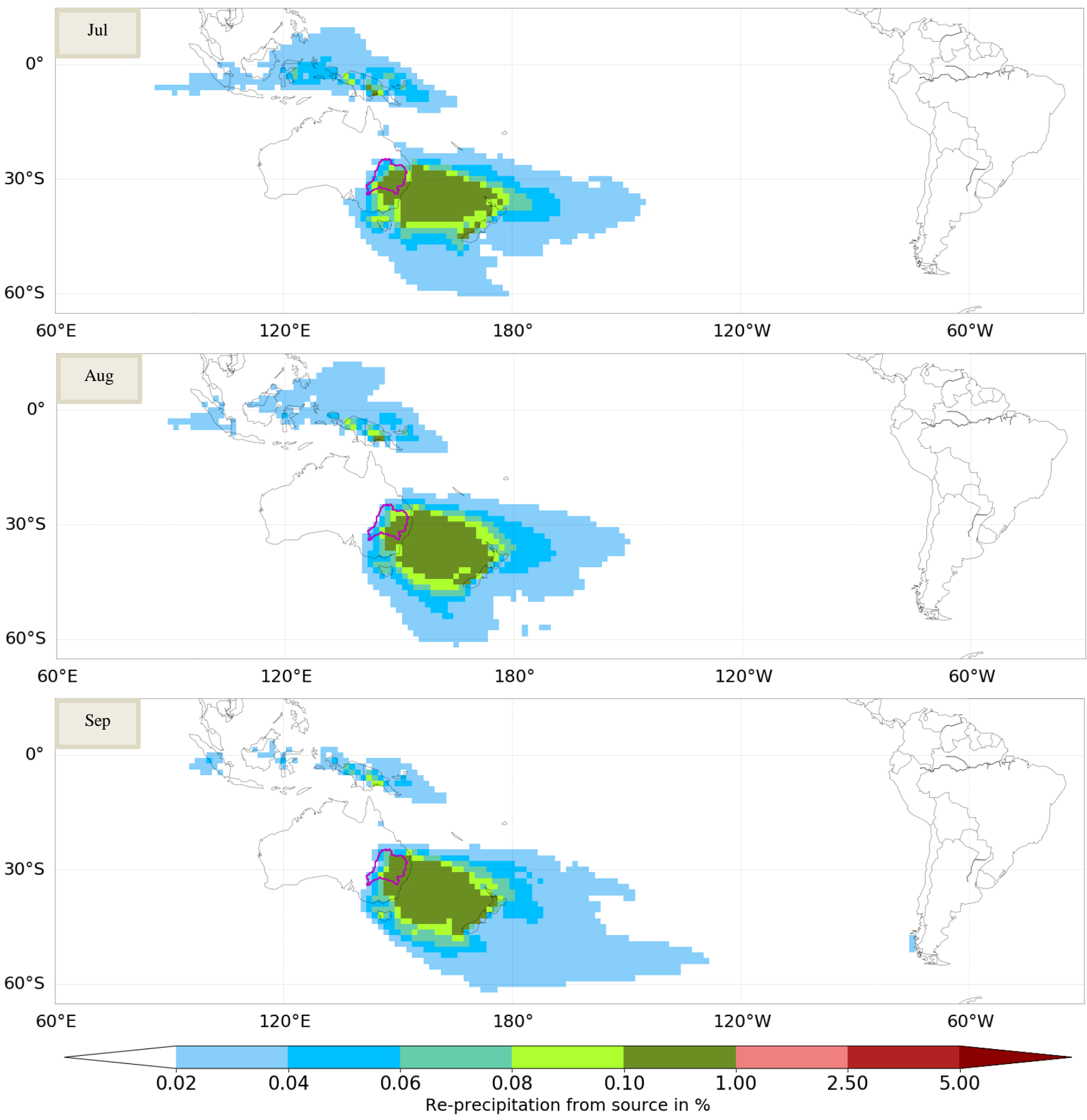

Figure S35 Monthly evaporationsheds (Jul = July, Aug = August, Sep = September) for the basin with the ID 2245569 (part of the Murray-Darling basin), $E_{\text {input }}: 22.0$ mm/month (Jul) / 25.6 mm/month (Aug) / 36.6 mm/month (Sep), Unassigned : $0.5 \%$ (Jul) / 0.5 $\%$ (Aug) / $0.6 \%$ (Sep), Colored area covers $60.1 \%$ (Jul) / $60.6 \%$ (Aug) / $61.7 \%$ (Sep) of the assigned water 


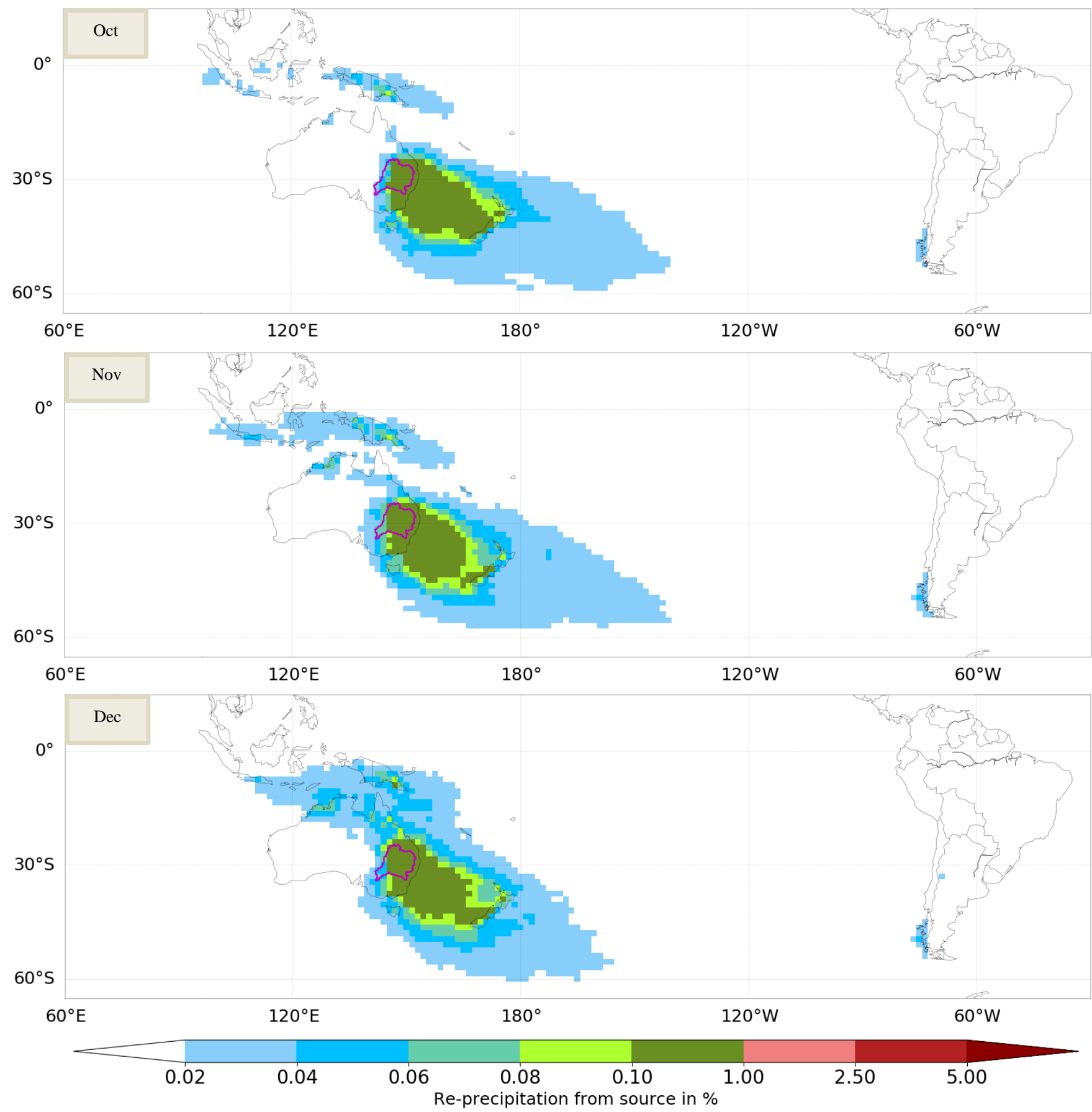

Figure S36 Monthly evaporationsheds $($ Oct $=$ October, Nov $=$ November, Dec $=$ December $)$ for the basin with the ID $2245569($ part of the Murray-Darling basin), $E_{\text {input }}: 48.7 \mathrm{~mm} / \mathrm{month}($ Oct) $/ 57.2 \mathrm{~mm} / \mathrm{month}$ (Nov) / $64.4 \mathrm{~mm} / \mathrm{month}$ (Dec), Unassigned : $0.6 \%$ (Oct) / $0.6 \%$ (Nov) / $0.5 \%$ (Dec), Colored area covers $59.3 \%$ (Oct) / $62.0 \%$ (Nov) / $64.0 \%$ (Dec) of the assigned water 

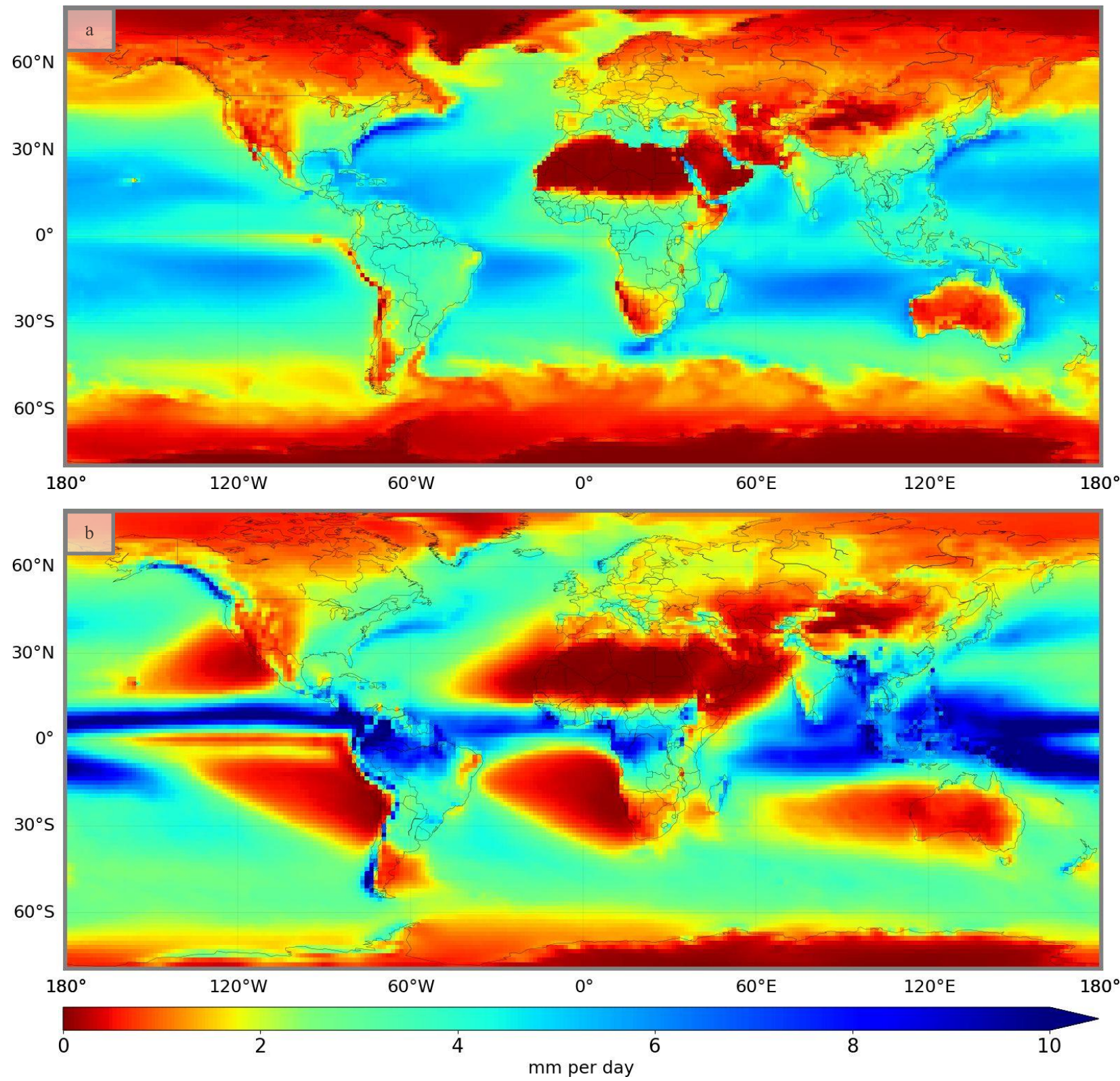

Figure S37 Average evaporation (a) and precipitation (b) in mm per day based on the ERA-Interim reanalysis (Berrisford et al., 2011; Dee et al., 2011); considered time period: 2001 to 2018 


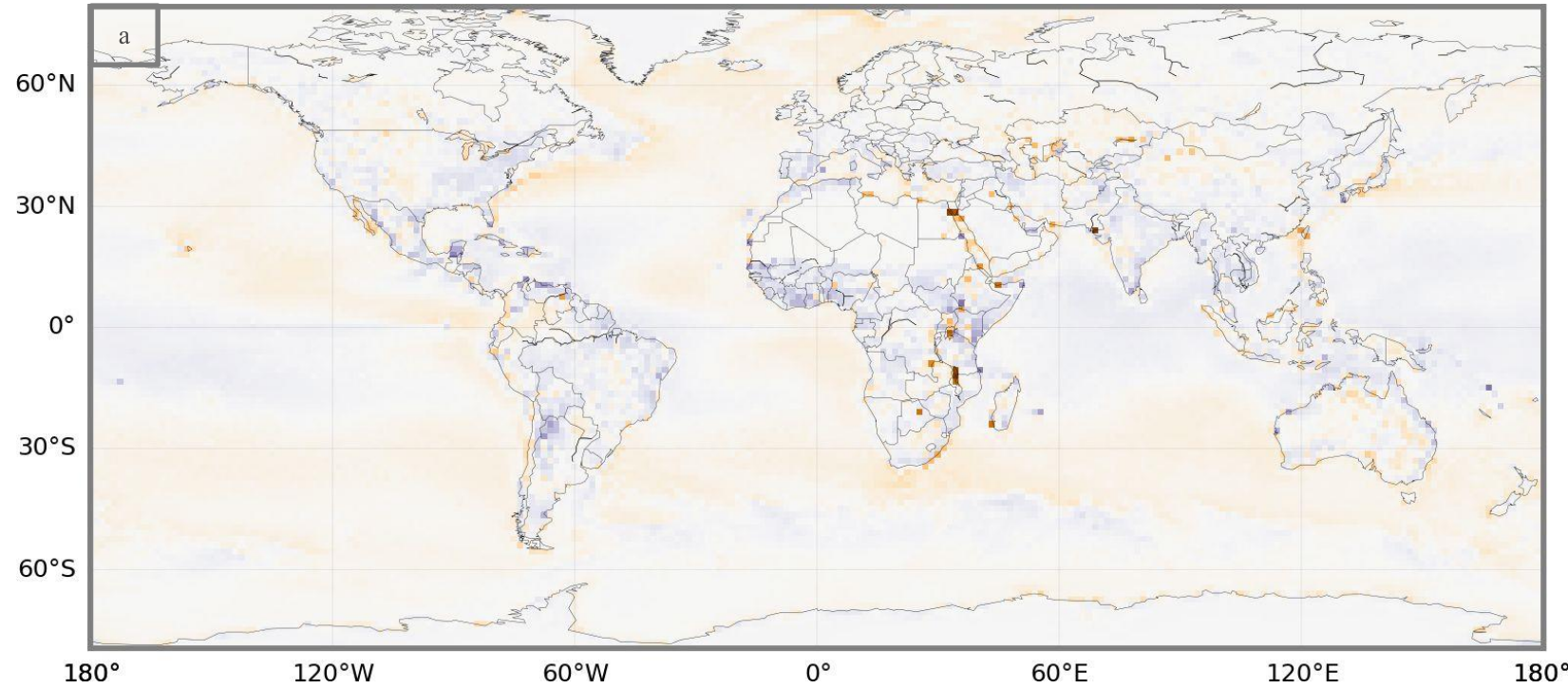

575

580

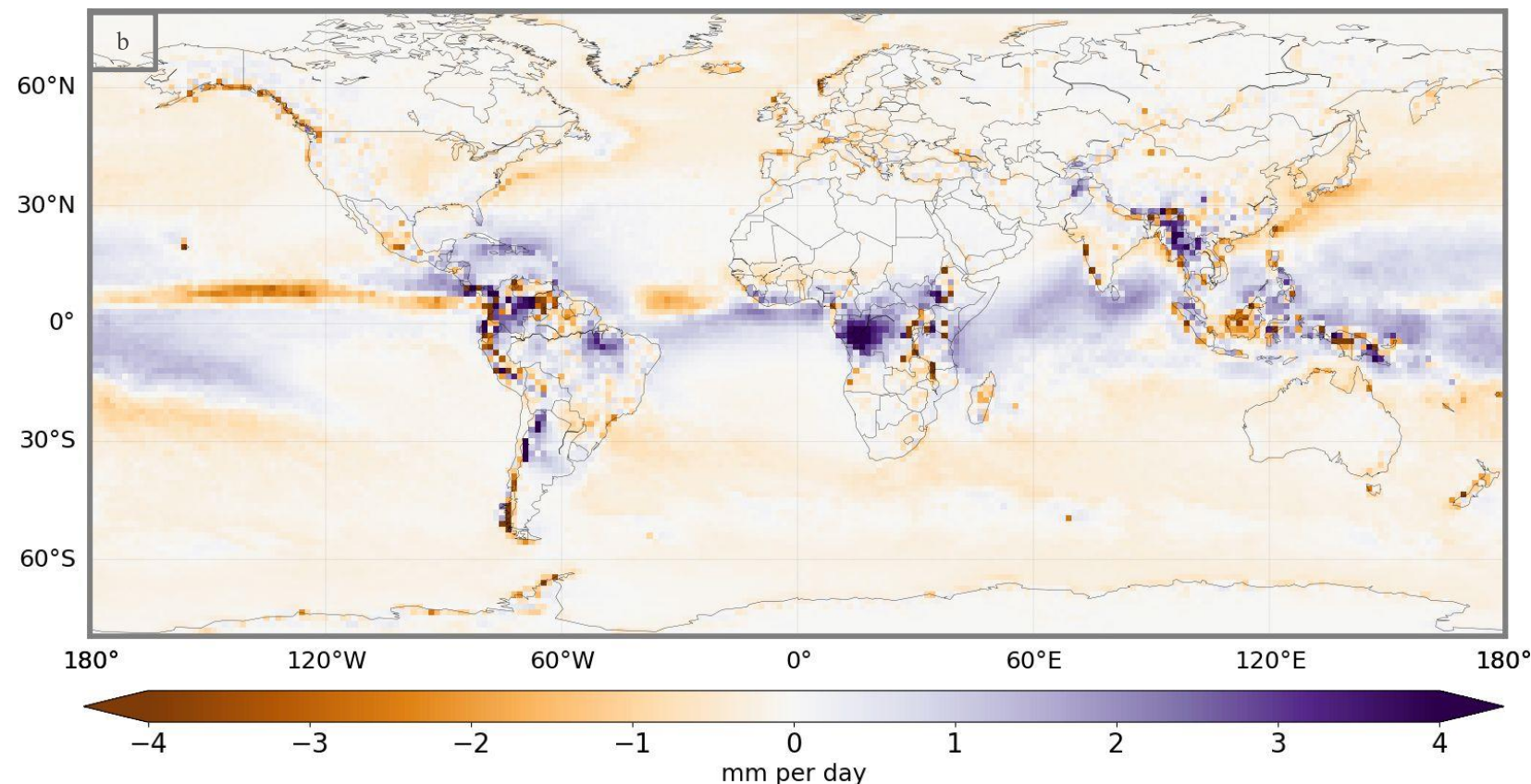

Figure S38 Differences between ERA-Interim (Berrisford et al., 2011; Dee et al., 2011) and ERA5 (Hersbach et al., 2020) regarding the average evaporation (a) and precipitation (b) in mm per day (ERA-Interim minus ERA5); considered time period: 2001 to 2018 
Methodological details regarding the continental comparison of the average evaporation and precipitation between ERA-Interim (Berrisford et al., 2011; Dee et al., 2011), ERA5 (Hersbach et al., 2020) and the study by Rodell et al.

Regarding the continental comparison of the average evaporation and precipitation between ERA-Interim (ERA-I), ERA5 and the study by Rodell et al. (2015) (Table 4 of the main article), we highlight the following two methodological elements:

- In order to enable a comparison of ERA-I and ERA5 to the continental results of the study by Rodell et al, values for the average evaporation and precipitation in ERA-I / ERA5 needed first to be aggregated to continental scales. We relied within this context on the country mask used for our article (Cun, 2016) and grouped within a second step our country results to continents. An overview on this grouping procedure can be gained through Table S1, which is presented below. Slight differences in continental delineations to the study of Rodell et al. (2015) might be possible but are considered as negligible small.

- We modified regarding the comparison the covered time horizon of the ERA-I and ERA5 data while excluding all data outside the first decade of the $21^{\text {st }}$ century (2011 to 2018). This procedure led to a relatively high temporal overlap of the two data sources in comparison to Rodell et al (2015).

610 
Table S1 Grouping of countries for the aggregation of the ERA-Interim and ERA5 data on evaporation and precipitation (Berrisford et al., 2011; Dee et al., 2011) to continental scales

\section{North America}

Anguilla, Antigua and Barbuda, Aruba, Bahamas, Barbados, Belize, Bermuda, Bonaire, British Virgin Islands, Canada, Cayman Islands, Clipperton Island, Costa Rica, Cuba, Curaçao, Dominica, Dominican Republic, El Salvador, Greenland, Grenada, Guadeloupe, Guatemala, Haiti, Honduras, Jamaica, Martinique, Mexico, Montserrat, Navassa Island, Nicaragua, Panama, Puerto Rico, Saint Barthélemy, Saint Kitts and Nevis, Saint Lucia, Saint Martin, Saint Pierre and Miquelon, Saint Vincent and the Grenadines, Sint Maarten, Trinidad and Tobago, Turks and Caicas Islands, United States, Virgin Islands

\section{South America}

Argentina, Bolivia, Bouvet Island, Brazil, Chile, Colombia, Ecuador, Falkland Islands (Islas Malvinas), French Guiana, Guyana, Paraguay, Peru, South Georgia and the South Sandwich Islands, Suriname, Uruguay, Venezuela

\section{Eurasia}

Åland, Afghanistan, Albania, Andorra, Armenia, Austria, Azerbaijan, Bahrain, Brunei, Bangladesh, Belarus, Belgium, Bhutan, Bosnia and Herzegovina, British Indian Ocean Territory, Bulgaria, Burma, Cambodia, China, Christmas Island, Cocos (Keeling) Islands, Croatia, Cyprus, Czech Republic, Denmark, Estonia, Faroe Islands, Finland, France, Palestine, Georgia, Germany, Gibraltar, Greece, Guernsey, Hong Kong, Hungary, Iceland, India, Indonesia, Iran, Iraq, Ireland, Isle of Man, Israel, Italy, Japan, Jersey, Jordan, Kazakhstan, Kuwait, Kyrgyzstan, Laos, Latvia, Lebanon, Liechtenstein, Lithuania, Luxembourg, Macau, Macedonia, Malaysia, Maldives, Malta, Moldova, Monaco, Mongolia, Montenegro, Nepal, Netherlands, North Korea, Norway, Oman, Pakistan, Paracel Islands, Philippines, Poland, Portugal, Qatar, Romania, Russia, San Marino, Saudi Arabia, Serbia, Singapore, Slovakia, Slovenia, South Korea, Spain, Spratly Islands, Sri Lanka, Svalbard and Jan Mayen, Sweden, Switzerland, Syria, Taiwan, Tajikistan, Thailand, Timor-Leste, Turkey, Turkmenistan,

Ukraine, United Arab Emirates, United Kingdom, Uzbekistan, Vatican City, Vietnam, Yemen

\section{Africa}

Algeria, Angola, Benin, Botswana, Burkina Faso, Burundi, Cameroon, Cape Verde, Central African Republic, Chad, Comoros, Congo, DR Congo, Côte d'Ivoire, Djibouti, Egypt, Equatorial Guinea, Eritrea, Ethiopia, Europa Island, French Southern and Antarctic Lands, Gabon, Gambia, Ghana, Glorioso Islands, Guinea, Guinea-Bissau, Heard Island and McDonald Islands, Juan De Nova Island, Kenya, Lesotho, Liberia, Libya, Madagascar, Malawi, Mali, Mauritania, Mauritius, Mayotte, Morocco, Mozambique, Namibia, Niger, Nigeria, Reunion, Rwanda, Saint Helena, Sao Tome and Principe, Senegal, Seychelles, Sierra Leone, Somalia, South Africa, Sudan / South Sudan,

Swaziland, Tanzania, Togo, Tromelin Island, Tunisia, Uganda, Western Sahara, Zambia, Zimbabwe

\begin{tabular}{|l|}
\hline \multicolumn{1}{c}{ Oceania } \\
\hline American Samoa, Ashmore and Cartier Islands, Baker Island, Cook Islands, Coral Sea Islands, Federated States of Micronesia, Fiji, \\
French Polynesia, Guam, Howland Island, Jarvis Island, Kingman Reef, Kiribati, Marshall Islands, Nauru, New Caledonia, New Zealand, \\
Niue, Norfolk Island, Northern Mariana Islands, Palau, Vanuatu, Palmyra Atoll, Papua New Guinea, Pitcairn Islands, Samoa, Solomon \\
Islands, Tokelau, Tonga, Tuvalu, Wake Island, Wallis and Futuna
\end{tabular}

\section{Unassigned regions}

Johnston Atoll, Midway Islands 
Table S2 Terrestrial evaporative source (TES - unit: \%) as well as the country internal evaporative source (CIES - unit: \%) for precipitation in different countries - Comparison of the results between the 3D QIBT model (fed with NCEP-DOE AMIP-II data (Kanamitsu et al., 2002) for wind and evaporation and CMAP data (Xie and Arkin, 1997) for precipitation) applied by Dirmeyer et al. (2009) and the WAM-2layers model (fed with ERA-Interim data (Berrisford et al., 2011; Dee et al., 2011))

\begin{tabular}{|c|c|c|c|c|}
\hline & \multicolumn{2}{|c|}{ TES in \% } & \multicolumn{2}{|c|}{ CIES in \% } \\
\hline & 3D QIBT & WAM-2layers & 3D QIBT & WAM-2 layers \\
\hline \multicolumn{5}{|l|}{ North America } \\
\hline Belize & 19.5 & 15.5 & 0.5 & 1.4 \\
\hline Canada & 69.7 & 38.6 & 54.8 & 17.4 \\
\hline Costa Rica & 34.3 & 19.3 & 2.4 & 1.6 \\
\hline El Salvador & 30.0 & 22.9 & 1.4 & 1.7 \\
\hline Guatemala & 25.3 & 22.8 & 4.0 & 4.6 \\
\hline Honduras & 24.7 & 18.9 & 4.2 & 4.6 \\
\hline Mexico & 39.7 & 28.6 & 28.4 & 16.2 \\
\hline Nicaragua & 25.9 & 16.7 & 5.1 & 2.7 \\
\hline Panama & 42.6 & 25.1 & 5.4 & 2.1 \\
\hline United States & 52.5 & 30.2 & 43.2 & 18.3 \\
\hline \multicolumn{5}{|l|}{ South America } \\
\hline Argentina & 59.5 & 50.6 & 27.9 & 19.0 \\
\hline Bolivia & 82.7 & 59.4 & 24.2 & 16.0 \\
\hline Brazil & 56.7 & 36.7 & 46.3 & 28.9 \\
\hline Chile & 8.1 & 4.3 & 5.4 & 1.4 \\
\hline Colombia & 49.9 & 37.1 & 10.9 & 11.6 \\
\hline Ecuador & 62.7 & 38.5 & 4.9 & 7.6 \\
\hline French Guiana & 14.5 & 12.0 & 2.6 & 2.3 \\
\hline Guyana & 19.1 & 16.4 & 3.2 & 3.2 \\
\hline Paraguay & 90.0 & 61.9 & 13.0 & 6.5 \\
\hline Peru & 71.8 & 49.2 & 25.9 & 16.5 \\
\hline Suriname & 18.2 & 14.8 & 2.8 & 3.0 \\
\hline Uruguay & 75.1 & 55.3 & 8.1 & 2.8 \\
\hline Venezuela & 29.4 & 27.0 & 9.1 & 9.8 \\
\hline \multicolumn{5}{|l|}{ Europe } \\
\hline Albania & 31.9 & 31.3 & 2.6 & 1.3 \\
\hline Armenia & 60.8 & 59.3 & 3.9 & 3.2 \\
\hline Austria & 54.4 & 41.9 & 6.7 & 2.9 \\
\hline Azerbaijan & 59.2 & 51.6 & 6.5 & 4.0 \\
\hline Belarus & 67.2 & 42.1 & 12.3 & 3.5 \\
\hline
\end{tabular}




\begin{tabular}{|c|c|c|c|c|}
\hline & \multicolumn{2}{|c|}{ TES in \% } & \multicolumn{2}{|c|}{ CIES in \% } \\
\hline & 3D QIBT & WAM-2layers & 3D QIBT & WAM-2 layers \\
\hline Belgium & 26.7 & 25 & 2.9 & 1.0 \\
\hline Bosnia and Herzegovina & 42.7 & 33.8 & 6.6 & 1.9 \\
\hline Bulgaria & 53.3 & 42.2 & 7.2 & 4.2 \\
\hline Croatia & 47.3 & 33.7 & 5.1 & 1.7 \\
\hline Czech Republic & 54.5 & 38.6 & 5.5 & 2.5 \\
\hline Denmark & 27.1 & 25.1 & 2.9 & 1.1 \\
\hline Estonia & 52.8 & 33.5 & 4.7 & 1.3 \\
\hline Finland & 58.7 & 34.8 & 19.2 & 3.3 \\
\hline France & 26.0 & 24.7 & 12.6 & 5.5 \\
\hline Georgia & 60.9 & 53.7 & 7.3 & 4.0 \\
\hline Germany & 39.2 & 31.2 & 11.9 & 4.3 \\
\hline Greece & 30.2 & 31.6 & 8.2 & 3.7 \\
\hline Hungary & 60.8 & 40.1 & 7.1 & 2.7 \\
\hline Iceland & 16.8 & 16.7 & 8.8 & 1.0 \\
\hline Ireland & 11.1 & 16.8 & 5.3 & 1.3 \\
\hline Italy & 39.8 & 33.6 & 14.2 & 5.6 \\
\hline Latvia & 54.0 & 35.6 & 4.8 & 1.6 \\
\hline Lithuania & 54.4 & 37.3 & 4.9 & 1.7 \\
\hline Luxembourg & 28.8 & 26.4 & 0.4 & 0.2 \\
\hline Macedonia & 37.6 & 38.8 & 1.4 & 1.6 \\
\hline Moldova & 70.1 & 45.7 & 3.4 & 1.5 \\
\hline Netherlands & 25.0 & 24.1 & 3.1 & 1.1 \\
\hline Norway & 26.0 & 23.8 & 10.9 & 2.3 \\
\hline Poland & 56.1 & 38.5 & 14.0 & 4.1 \\
\hline Portugal & 9.9 & 12.4 & 3.9 & 1.6 \\
\hline Romania & 66.1 & 46.5 & 15.3 & 6.3 \\
\hline Russia & 83.2 & 53.9 & 64.7 & 27.8 \\
\hline Slovakia & 63.2 & 42.2 & 5.6 & 1.4 \\
\hline Slovenia & 53.8 & 40.5 & 3.3 & 1.5 \\
\hline Spain & 19.3 & 21.0 & 12.6 & 6.3 \\
\hline Sweden & 42.8 & 31.2 & 18.7 & 4.0 \\
\hline Switzerland & 42.5 & 36.5 & 6.4 & 2.3 \\
\hline Ukraine & 69.0 & 43.5 & 19.0 & 6.6 \\
\hline United Kingdom & 14.9 & 19.1 & 6.4 & 2.2 \\
\hline
\end{tabular}




\begin{tabular}{|c|c|c|c|c|}
\hline & \multicolumn{2}{|c|}{ TES in $\%$} & \multicolumn{2}{|c|}{ CIES in \% } \\
\hline & 3D QIBT & WAM-2layers & 3D QIBT & WAM-2 layers \\
\hline \multicolumn{5}{|l|}{ Africa } \\
\hline Algeria & 24.6 & 31.6 & 8.3 & 5.0 \\
\hline Angola & 81.3 & 58.1 & 23.6 & 20.9 \\
\hline Botswana & 82.9 & 56.6 & 17.9 & 10.9 \\
\hline Burkina Faso & 73.5 & 63.0 & 10.3 & 7.9 \\
\hline Burundi & 55.8 & 40.8 & 1.9 & 3.2 \\
\hline Cameroon & 78.6 & 64.0 & 11.4 & 11.7 \\
\hline Congo & 80.9 & 58.8 & 10.6 & 9.5 \\
\hline Cote d'Ivoire & 61.2 & 47.6 & 9.1 & 9.4 \\
\hline Djibouti & 47.8 & 37.5 & 1.3 & 0.9 \\
\hline Egypt & 17.6 & 23.4 & 2.8 & 2.7 \\
\hline Equatorial Guinea & 73.3 & 60.8 & 1.2 & 4.2 \\
\hline Eritrea & 51.9 & 48.0 & 4.0 & 4.1 \\
\hline Ethiopia & 56.4 & 44.2 & 25.6 & 15.9 \\
\hline Kenya & 34.8 & 22.9 & 11.9 & 9.2 \\
\hline Lesotho & 68.9 & 48.7 & 3.9 & 2.7 \\
\hline Liberia & 50.5 & 44.1 & 3.5 & 4.3 \\
\hline Libya & 19.8 & 28.5 & 5.0 & 2.3 \\
\hline Madagascar & 27.4 & 18.1 & 20.5 & 11.6 \\
\hline Malawi & 60.0 & 37.1 & 6.6 & 3.5 \\
\hline Mali & 31.9 & 66.8 & 17.4 & 10.7 \\
\hline Mauritania & 58.7 & 62.8 & 8.6 & 4.2 \\
\hline Morocco & 12.7 & 21.8 & 7.7 & 5.2 \\
\hline Mozambique & 49.5 & 29.3 & 20.2 & 11.5 \\
\hline
\end{tabular}




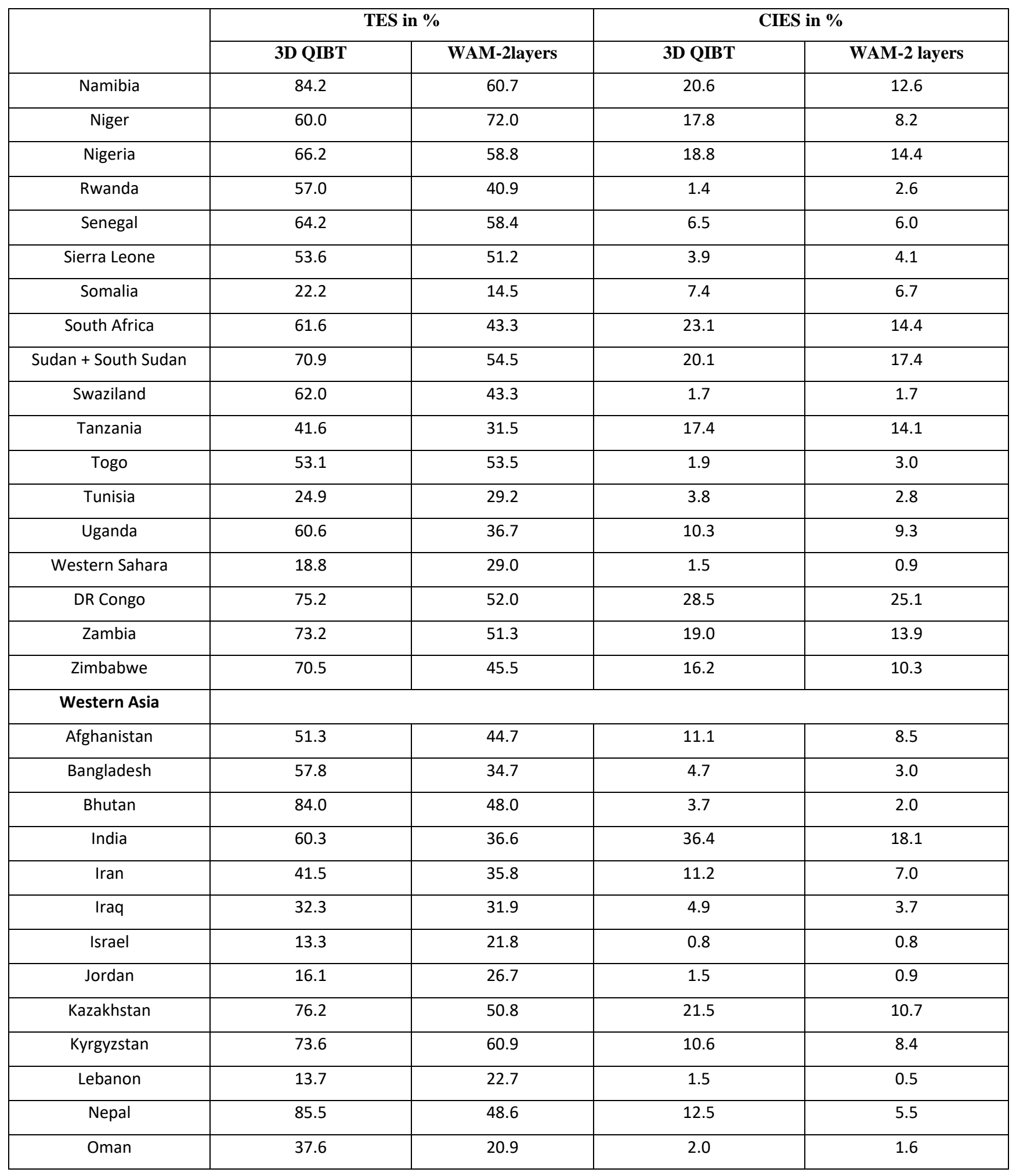




\begin{tabular}{|c|c|c|c|c|}
\hline & \multicolumn{2}{|c|}{ TES in \% } & \multicolumn{2}{|c|}{ CIES in \% } \\
\hline & 3D QIBT & WAM-2layers & 3D QIBT & WAM-2 layers \\
\hline Pakistan & 67.8 & 50.8 & 15.8 & 12.9 \\
\hline Qatar & 45.5 & 24.0 & 0.4 & 0.3 \\
\hline Saudi Arabia & 46.3 & 30.2 & 8.2 & 6.4 \\
\hline Sri Lanka & 16.7 & 13.1 & 5.4 & 2.3 \\
\hline Syria & 23.1 & 28.8 & 4.4 & 2.7 \\
\hline Tajikistan & 63.1 & 53.9 & 6.9 & 6.3 \\
\hline Turkey & 40.9 & 36.3 & 22.3 & 9.8 \\
\hline Turkmenistan & 50.8 & 39.0 & 4.3 & 3.3 \\
\hline United Arab Emirates & 47.2 & 23.5 & 1.7 & 1.5 \\
\hline Uzbekistan & 59.2 & 42.7 & 5.3 & 4.2 \\
\hline Yemen & 50.4 & 39.1 & 5.9 & 5.6 \\
\hline \multicolumn{5}{|l|}{ Eastern Asia \& Oceania } \\
\hline Australia & 38.6 & 22.9 & 37.9 & 20.7 \\
\hline Burma & 49.3 & 29.3 & 12.6 & 6.7 \\
\hline Cambodia & 23.0 & 19.0 & 5.8 & 5.9 \\
\hline China & 74.8 & 56.2 & 41.4 & 25.9 \\
\hline Indonesia & 28.2 & 18.6 & 22.3 & 12.2 \\
\hline Japan & 36.6 & 26.6 & 10.1 & 3.3 \\
\hline Laos & 43.7 & 30.0 & 6.6 & 4.1 \\
\hline Malaysia & 30.5 & 18.3 & 10.5 & 6.3 \\
\hline Mongolia & 95.7 & 80.3 & 30.8 & 12.4 \\
\hline New Zealand & 9.9 & 8.8 & 6.7 & 2.2 \\
\hline North Korea & 67.9 & 48.6 & 7.4 & 2.4 \\
\hline Papua New Guinea & 29.3 & 12.2 & 19.1 & 7.2 \\
\hline Philippines & 11.6 & 9.3 & 6.3 & 3.4 \\
\hline South Korea & 47.2 & 32.4 & 5.5 & 1.6 \\
\hline Thailand & 30.3 & 22.4 & 9.3 & 6.8 \\
\hline Vietnam & 33.6 & 25.7 & 6.7 & 4.1 \\
\hline
\end{tabular}


Table S3 Top 10 sources of precipitation for the country Brazil - Comparison between results from the 3D QIBT model (fed with NCEP-DOE AMIP-II data (Kanamitsu et al., 2002) for wind and evaporation and CMAP data (Xie and Arkin, 1997) for precipitation) and the WAM-2layers model (fed with ERA-Interim data (Berrisford et al., 2011; Dee et al., 2011)) - Sources appearing in both lists are displayed in bold font; $\mathrm{UA}=$ Unassigned fractions due to system boundary losses

\begin{tabular}{|c|c|c|c|c|}
\hline \multirow{2}{*}{$\begin{array}{c}\text { Rank } \\
1\end{array}$} & \multicolumn{4}{|c|}{ Top 10 sources of precipitation for Brazil in $\%$} \\
\hline & Brazil & 46.3 & Sea & 63.3 \\
\hline 2 & Sea & 43.3 & Brazil & 28.9 \\
\hline 3 & Bolivia & 2.4 & Bolivia & 1.2 \\
\hline 5 & Argentina & 1.2 & Argentina & 0.6 \\
\hline 6 & Paraguay & 0.9 & Angola & 0.4 \\
\hline 7 & Nigeria & 0.6 & Paraguay & 0.4 \\
\hline 8 & Côte d'Ivoire & 0.5 & Venezuela & 0.3 \\
\hline
\end{tabular}

Table S4 Top 10 sources of precipitation for the country Egypt - Comparison between results from the 3D QIBT model (fed with NCEP-DOE AMIP-II data (Kanamitsu et al., 2002) for wind and evaporation and CMAP data (Xie and Arkin, 1997) for precipitation) and the WAM-2layers model (fed with ERA-Interim data (Berrisford et al., 2011; Dee et al., 2011)) - Sources appearing in both lists are displayed in bold font; $\mathrm{UA}=$ Unassigned fractions due to system boundary losses

\begin{tabular}{|c|c|c|c|c|}
\hline \multirow{3}{*}{$\begin{array}{c}\text { Rank } \\
1\end{array}$} & \multicolumn{4}{|c|}{ Top 10 sources of precipitation for Egypt in \% } \\
\hline & \multicolumn{2}{|l|}{ 3D QIBT } & \multicolumn{2}{|c|}{ WAM-2layers } \\
\hline & Sea & 82.4 & Sea & 76.6 \\
\hline 2 & Libya & 3.3 & Egypt & 2.7 \\
\hline 3 & Egypt & 2.8 & Turkey & 1.9 \\
\hline 4 & Algeria & 1.4 & Greece & 1.2 \\
\hline 5 & Greece & 1.0 & Libya & 1.1 \\
\hline 6 & Spain & 1.0 & Sudan / South Sudan & 0.9 \\
\hline 7 & Sudan / South Sudan & 0.7 & Algeria & 0.9 \\
\hline 8 & Morocco & 0.6 & Nigeria & 0.8 \\
\hline 9 & Turkey & 0.6 & United States & 0.8 \\
\hline 10 & Other land & 6.0 & Other land + UA & 13.1 \\
\hline
\end{tabular}


Table S5 Top 10 sources of precipitation for the country Laos - Comparison between results from the 3D QIBT model (fed with

650 NCEP-DOE AMIP-II data (Kanamitsu et al., 2002) for wind and evaporation and CMAP data (Xie and Arkin, 1997) for precipitation) and the WAM-2layers model (fed with ERA-Interim data (Berrisford et al., 2011; Dee et al., 2011)) - Sources appearing in both lists are displayed in bold font; $\mathrm{UA}=$ Unassigned fractions due to system boundary losses

\begin{tabular}{|c|c|c|c|c|}
\hline \multirow{3}{*}{$\begin{array}{c}\text { Rank } \\
1\end{array}$} & \multicolumn{4}{|c|}{ Top 10 sources of precipitation for Laos in $\%$} \\
\hline & \multicolumn{2}{|c|}{ 3D QIBT } & \multicolumn{2}{|c|}{ WAM-2layers } \\
\hline & Sea & 56.3 & Sea & 70.0 \\
\hline 2 & Thailand & 9.4 & Thailand & 6.4 \\
\hline 3 & Burma & 6.9 & Laos & 4.1 \\
\hline 5 & India & 6.2 & Burma & 3.6 \\
\hline 6 & China & 5.2 & China & 3.4 \\
\hline 7 & Vietnam & 4.0 & Vietnam & 1.9 \\
\hline 8 & Cambodia & 2.2 & Cambodia & 1.3 \\
\hline
\end{tabular}

655

660 


\section{References of the supplement}

Berrisford, P., Dee, D. P., Poli, P., Brugge, R., Fielding, K., Fuentes, M., Kållberg, P., Kobayashi, S., Uppala, S. and Simmons, A.: The ERA-Interim archive Version 2.0. ERA Report Series 1. [online] Available from: http://www.ecmwf.int/en/elibrary/8174-era-interim-archive-version-20, 2011.

Cun, J. L.: Global country boundaries, [online] Available from:
https://www.arcgis.com/home/item.html?id=2ca75003ef9d477fb22db19832c9554f (Accessed 27 September 2019), 2016.

Dee, D. P., Uppala, S. M., Simmons, A. J., Berrisford, P., Poli, P., Kobayashi, S., Andrae, U., Balmaseda, M. A., Balsamo, G., Bauer, P., Bechtold, P., Beljaars, A. C. M., van de Berg, L., Bidlot, J., Bormann, N., Delsol, C., Dragani, R., Fuentes, M., Geer, A. J., Haimberger, L., Healy, S. B., Hersbach, H., Hólm, E. V., Isaksen, L., Kållberg, P., Köhler, M., Matricardi, M., 680 Mcnally, A. P., Monge-Sanz, B. M., Morcrette, J. J., Park, B. K., Peubey, C., de Rosnay, P., Tavolato, C., Thépaut, J. N. and Vitart, F.: The ERA-Interim reanalysis: Configuration and performance of the data assimilation system, Q. J. R. Meteorol. Soc., 137(656), 553-597, doi:10.1002/qj.828, 2011.

Dirmeyer, P. A., Brubaker, K. L. and DelSole, T.: Import and export of atmospheric water vapor between nations, J. Hydrol., 365(1-2), 11-22, doi:10.1016/j.jhydrol.2008.11.016, 2009.

Hersbach, H., Bell, B., Berrisford, P., Hirahara, S., Horányi, A., Muñoz-Sabater, J., Nicolas, J., Peubey, C., Radu, R., Schepers, D., Simmons, A., Soci, C., Abdalla, S., Abellan, X., Balsamo, G., Bechtold, P., Biavati, G., Bidlot, J., Bonavita, M., de Chiara, G., Dahlgren, P., Dee, D., Diamantakis, M., Dragani, R., Flemming, J., Forbes, R., Fuentes, M., Geer, A., Haimberger, L., Healy, S., Hogan, R. J., Hólm, E., Janisková, M., Keeley, S., Laloyaux, P., Lopez, P., Lupu, C., Radnoti, G., de Rosnay, P., Rozum, I., Vamborg, F., Villaume, S. and Thépaut, J.-N.: The ERA5 Global Reanalysis, R. Meteorol. Soc., Preprint, 690 doi:10.1002/qj.3803., 2020.

Kanamitsu, M., Ebisuzaki, W., Woollen, J., Yang, S. K., Hnilo, J. J., Fiorino, M. and Potter, G. L.: NCEP-DOE AMIP-II reanalysis (R-2), Bull. Am. Meteorol. Soc., doi:10.1175/bams-83-11-1631(2002)083<1631:nar>2.3.co;2, 2002.

Link, A., Van der Ent, R., Berger, M., Eisner, S. and Finkbeiner, M.: The fate of land evaporation - A global dataset, PANGAEA, , doi:https://doi.org/10.1594/PANGAEA.908705, 2019a.

695 Link, A., Van der Ent, R., Berger, M., Eisner, S. and Finkbeiner, M.: Tool for Visualizing the Fate of Land Evaporation, [online] Available from: https://wf-tools.see.tu-berlin.de/wf-tools/evaporationshed/\#/ (Accessed 16 December 2019), $2019 \mathrm{~b}$. Rodell, M., Beaudoing, H. K., L’Ecuyer, T. S., Olson, W. S., Famiglietti, J. S., Houser, P. R., Adler, R., Bosilovich, M. G., Clayson, C. A., Chambers, D., Clark, E., Fetzer, E. J., Gao, X., Gu, G., Hilburn, K., Huffman, G. J., Lettenmaier, D. P., Liu, W. T., Robertson, F. R., Schlosser, C. A., Sheffield, J. and Wood, E. F.: The observed state of the water cycle in the early 700 twenty-first century, J. Clim., 28(21), 8289-8318, doi:10.1175/JCLI-D-14-00555.1, 2015.

Van der Ent, R. J.: A new view on the hydrological cycle over continents, Ph.D. thesis, Delft University of Technology, Delft, 96 pp., 2014.

Xie, P. and Arkin, P. A.: Global Precipitation: A 17-Year Monthly Analysis Based on Gauge Observations, Satellite Estimates, 
and Numerical Model Outputs, Bull. Am. Meteorol. Soc., doi:10.1175/1520-0477(1997)078<2539:GPAYMA>2.0.CO;2, 7051997. 